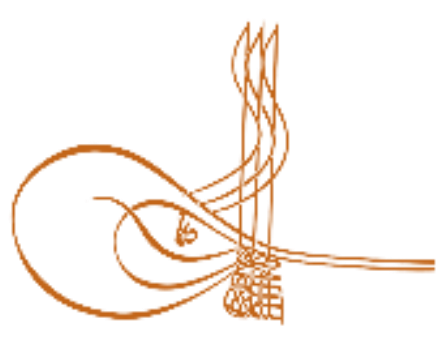

www.turkishstudies.net/social
Turkish Studies - Social Sciences

eISSN: $2667-5617$

Research Article / Araștırma Makalesi

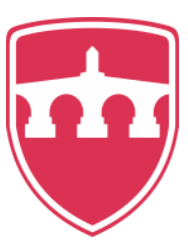

INTERNATIONAL

BALKAN

UNIVERSITY

Sponsored by IBU

\title{
İki Dünya Arasında Bir Elçi: İvan Daniloviç Hohlov'un Buhara Misyonu (1620-1622)
}

Between the Two Worlds: The Mission of Ivan Danilovich Khokhlov in Bukhara (1620-1622)

\author{
Mesut Karakulak*
}

\begin{abstract}
Russian Tsarism, facing central governments such as a strong Ottoman State from the South and European States in the West in 16th and 17th centuries, expanded towards to the East, that is, Turkistan and its region. However, this new field of progress was as in the West full of unknowns for the Russians. For this reason, the Russians created their first activities in Turkistan on the basis of exploring the region. So, a large number of diplomats and soldiers were sent to Turkistan, starting from the 19th century. These leading colonizers highlighted many military, administrative, geographical and cultural aspects of the Turkistan geography, full of mysteries for the Russians. Ultimately, the Russians had access to detailed information about the region within the framework of these eyewitness reports. The Tsarist Russian appointed many diplomats to explore the depths of Turkestan, Ivan Danilovich Khokhlov, who was one of them, was sent by Tsar Michael Feodorovich to Bukhara in order to rescue prisoners, the majority of whom were Russian nobles and imperial officials. This study discusses the travel notes of Hohlov, who completed the voyage to Bukhara with great difficulty between 1620-22 and saved some Russian prisoners. Khohlov's travel notes describe the chaotic environment in the Turkestan region in general and give detailed information about the personalities of the figures of that period. However, it gives little information about the geography, cultural and ethnic structure of the region. Nevertheless, these notes are important in terms of recognizing the world of the diplomat, who led to an unknown land in the early seventeenth century
\end{abstract}

Structured Abstract: In the seventeenth century, the Tsarist Russia developed multi-faceted interest relations and especially wanted to establish close contacts with the Turkestan and Iran geography, it was a complicated period (Smutnoe Vremia 1598-1613) for Russia. This chaotic period ended in 1613, when Mikhail Federovich (1613-1645), the first representative of the Romanov dynasty, took over Tsarist in Russia. However, when Federovic came to the throne, Moscow was devastated and the state was in the process of financial collapse. As the characteristic feature of the period of confusion, separationist movements started in places where central power is not felt, such as Astarhan, which Russia has just acquired, with its management gaps. The sending of Ivan Danilovich Hohlov to Astarhan and later to Bukhara as an ambassador in such a period is a declaration that the Russian Tsarist has survived this interregnum period. The Tsarist administration, which has not been in contact with the Turkestan khanates

\footnotetext{
* Dr., Ordu Üniversitesi, Fen-Edebiyat Fakültesi, Tarih Bölümü

Dr. Ordu University, Faculty of Science and Letters, Department of History

ORCID 0000-0002-0142-9170

mesut.karakulak@hotmail.com
}

Cite as/ Atıf: Karakulak, M. (2020). İki dünya arasında bir elçi: Ivan Daniloviç Hohlov'un Buhara misyonu (1620-

1622), Turkish Studies - Social, 15(1), 369-388. https://dx.doi.org/10.29228/TurkishStudies.40422

Received/Geliş: 03 January/Ocak 2019

Accepted/Kabul: 25 February/Şubat 2020

Copyright $(\mathcal{C}$ INTAC LTD, Turkey
Checked by plagiarism software

Published/Yayın: 29 February/Şubat 2020

CC BY-NC 4.0 
for a long time, continues its exploration expeditions in the region by making excuses for Russian prisoners with this mission. These missions prepared the basis for the expansionist policy of the Russian tsarist in Turkistan. These expeditions were also tools to strengthen the Tsar's rule over the steppe peoples.

Considering the relationship network established by Hohlov in the region, it is clear that Hive and Bukhara administrators were not afraid of Tsarist rule and they seek financial benefits. The dispatch of Russian official representatives during this period, although considered in the context of prisoners and commercial relations, the main mission was to recognize the steppe peoples. Although Hohlov strictly adhered to the instructions given to him, the information collected about the region remained superficial due to the lack of experts in the delegation such as geography, geodesy and mining. For this reason, at least one geodesy specialist has been added to the embassy delegation in the next expeditions. Hohlov, who was more successful than the embassy delegations sent to the region before him in the attempt to rescue Russian prisoners, vividly illustrated feudal competition and struggle within the region.

The Russian Tsarist gives written instructions, called nakaz/injunction, to the envoys he has appointed to engage in diplomatic relations. These are the mandatory rules for Russian ambassadors to the Turkestan region and include information on diplomatic customs, the correct use of the tsar's titles, the travel route, the goal of the diplomatic mission and how they can achieve them. The envoys had to comply with these instructions, they were forbidden to act outside the nakaz/injunction. In the instruction given to Hohlov, he was told to act within certain rules and was ordered not to take initiative on controversial issues between Tsar and Bukhara Khan. If the envoy was questioned by the Khan or another group, he would say that he was an envoy of the Great Tsar Mikhail Federovich. In addition, the gifts given by the tsar should be delivered directly to Khan, never an intermediary should be accepted. Hohlov should have been the first ambassador at the embassy reception ceremony of Bukhara Khanate. At the reception ceremony, Khan should have asked the health of the Tsar and convey his goodwill. If these diplomatic rituals were not practiced, they should not have remained in their presence. In fact, Tsar's desires were part of the early modern diplomacy, and this was not limited to the Russians. In the instruction given to Hohlov, essentially four main duties were assigned to him. The first one is to maintain the prestige of the tsar by ensuring the correct application of diplomatic rituals; the second is to declare that the period of internal turmoil in the Russian Tsarist was over; the third one is to save the Russian prisoners in Bukhara; Finally, establishing a commercial relationship. Khokhlov 's activities were shaped within these four main tasks. To what extent the ambassador performs these tasks and the relationship network is the primary problematic of this work.

Considering that Khokhlov was in the region for a long time, he completed his duties to a great extent. The diplomatic reports in this period consisted of the questioning made when the embassy committees returned. Russian diplomats still did not have the habit of keeping personal diaries in their foreign officials during this period. They only kept complex notes along the way in preparation for inquiries. The fact that Khokhlov 's information about Bukhara is superficial proves this situation. In this period, diversity in European travel notes, in-depth observations are not found in Russian travel notes. Russian diplomatic missions report only contain information about the tasks assigned. it is difficult to find personal statements with comments in their report. The superficiality in Khokhlov 's report is partly due to these habits, from the point of view of the ambassadors, and partly because he had to keep some of his personal notes in Urgench and then could not reach them.

Khokhlov, a mid-level nobleman, was not completely familiar with diplomacy, but he had previously participated in failed embassy activities and lived captive in Turkistan, In this way, he knew the people of the region closely and had a certain extent of network. Unlike previous envoys in his report, he was able to provide detailed information about local conflicts, power relations, alliances, and hostilities in the region.

Khokhlov, who set out to go to Bukhara in 1620, was waiting for many difficulties along his route. For this reason, Hohlov tried to gather information about the possible difficulties between Hive and Bukhara. There were translators, guards, merchants and various officials in the embassy delegation. However, Hohlov's reports are very discreet about the names of the officers in his suite. In fact, Hohlov, however, confused the titles and names of some Bukhara officers with whom he had a relationship in the region. Some of the main characters are visible in the envoy's reports. The most important of these were the translators Ivan Ivankov and Semeyka Gerasimov, who were in a vital position for the embassy. In this period, one of the great difficulties faced by the Russian Tsarist in diplomatic relations with the Turkistan geography was the

Turkish Studies - Social, 15(1) 
lack of staff who speak foreign languages. Embassy delegations also suffered from the same inefficiency. For this reason, the interpreters in the embassy delegations that he sent to the Turkistan region consisted of either Russian prisoners who had been in the region for a long time or Russianized Tatars. One of these Tatars was in Ivan Tirkov. From the reports of Khokhlov, we determine that high-level envoys accompanied him on his way back. One of them is the envoy of Bukhara Khanate, Adem Bey and the other is Hive envoy Rahim Kulu. On the way back to Khokhlov, Hive administrator İlbars Sultan's envoy Makhtamanbaydı was accompanied. For the Turkestan Khanates, who sent high-profile statesmen to Russia, the Tsarist was in a way a supreme authority. Nevertheless, what was the position of the khanates for the Russian Tsarist, and to what extent was Hohlov an ambassador? It is possible to answer these questions based on Hohlov's reports. Because the number of gerfalcons, who will send the Buhara Khan to Imamkulu as a gift, plays a key role here. Because while Tsar was gifting four gerfalcons to Imamkulu, much more gifts were sent to Savefi Shah in 1618. From this point of view, it can be said that the Turkestan Khanates and Safavid State are not in the same position and Khokhlov is not positioned as a high level ambassador.

Keywords: Tsar Michael Feodorovich I, Slaves, Captives, Tsardom of Russia, Bukhara, Khiva, Ivan Danilovich Khokhlov

Öz: Rus Çarlığının, XVI ve XVII. yüzyıllarda, Batı’dan, Avrupa Devletleri ve Güney’den güçlü bir Osmanlı Devleti gibi merkezi yönetimlerle karşı karşıya olması, ilerleme sahasının Doğu istikametinde yani Türkistan ve havalisinde gerçekleşmesine neden oldu. Ancak bu yeni ilerleme sahası Batı'da olduğu gibi Ruslar için de bilinmezliklerle doluydu. Bu nedenle Ruslar Türkistan'daki ilk faaliyetlerini bölgeyi keşfetme temelinde oluşturdu. Dolayısıyla XVI. yüzyıldan başlamak kaydıyla Türkistan'a çok sayıda diplomat ve asker gönderildi. Bu öncü kolonizatörler, Ruslar için gizemlerle dolu Türkistan coğrafyasının askeri, idari, coğrafi ve kültürel pek çok yönünü aydınlattı. Nihayetinde Ruslar bu görgü tanıklarının raporları çerçevesinde bölge hakkında tafsilatlı bilgiye erişmesini sağladı. Bu diplomatlar arasında Rus Çarı I. Mihail Federoviç tarafından Buhara'ya gönderilmesi kararlaştırılan İvan Daniloviç Hohlov, öncü bir rol oynadı. O, Buhara’ya çoğunluğu Rus asilzadesi ve imparatorluk görevlilerinden oluşan esirlerin kurtarılması için gönderildi. Bu çalışma 1620-1622 yılları arasında çok farklı zorluklarla Buhara seyahatini tamamlayan ve bir miktar Rus esirinin kurtulmasını sağlan İvan Daniloviç Hohlov'un yol boyunca tuttuğu notları konu almaktadır. Hohlov, Türkistan bölgesindeki kaotik ortamı genel çerçevede betimleyen, o dönem figürlerinin kişiliklerini yansıtan bilgiler sunsa da bölge coğrafyası, kültürel ve etnik yapısı hakkında oldukça az bilgi vermektedir. Buna rağmen XVII. yüzyılın başlarında bilinmeze doğru yol alan diplomatın dünyası dönemi tanımlamak adına önem arz etmektedir.

Anahtar Kelimeler: Çar I. Mihail Federoviç, kölelik, esirler, Rus Çarlığı, Buhara, Hive, İvan Daniloviç Hohlov

\section{Giriş}

Rusların Türkistan hanlıkları ve havalisindeki yayılmacılık politikası XV. yüzyıl gibi erken tarihlense de tam manasıyla I. Petro devri ile bu bölgeye ilgi ve alakasının belirginleşmeye başladığı bilinmekteydi. Rusya'nın Petro dönemine kadar Türkistan ile kurmaya çalıştığı ilişki ağ daha ziyade ticari, keşif ve bazı Rus esirlerin durumunu öğrenmek amacı gütmekteydi. Zira 1557 yılında öncelikle İngilizler adına Türkistan ve İran ile ticari ilişkiler kurma amacı ile yola çıkan ve aynı yıl Moskova'ya ulaşan İngiliz tüccar A. Jenkinson, Rusya adına Türkistan ile ilk siyasi teması gerçekleştiren kişi oldu (Barthold, 2004, s. 251; Özkan, 2019, ss. 166-167). 1558 y1lında Hive ve Buhara'ya gönderilen Jenkinson, önemli temaslarda bulunarak ertesi yıl Moskova’ya dönüş yapt1. Bu ilk temas Rusya'nın bu bölge hakkında son derece ehemmiyetli bilgiler edinmesini sağladi ${ }^{1}$.

Rusya’nın Türkistan’a ilgisini dönemin iç ve dış dinamikleri ile beraber düşünmek bu politikayı belirleyen esasların ne olduğu noktasında daha kesin bilgilere ulaşmamıza imkân sağlayacaktır. Bilindiği üzere Rus Çarı IV. İvan döneminde Kazan (1552) ve Astarhan Hanlığının

\footnotetext{
${ }^{1}$ Ayrıntılı bilgi için Bkz. (Jenkinson, 1886; Ükten, 2017, ss.141-143; Koç, 2017, ss. 61-90).
} 
(1556) Rus sınırlarına dâhil edilmesi ve akabinde Osmanlı Devleti tarafından düzenlenen Astarhan seferinin (1569) başarısızlık ile sonuçlanması, Rus yayılmacılığının önündeki engelleri en aza indirgemiştir (Kurat, 2001, ss. 136-156; İnalc1k, 1948, ss. 349-402). Nihayetinde Küçüm Han yönetimindeki Sibir Hanlığı da kolaylıkla Rus işgaline uğramıştır (Karamzin, 1843, ss. 223-224; Apollova, 1948, s. 186). XVI. yüzyılda Rusların büyük başarılar elde etmesi ve bu havalide yaşayan Türk topluluklarının hamisi konumunda bir devletin olmaması bu ilerleyişin daha ileri noktalara taşınmasına sebebiyet vermiştir. Nitekim çok geçmeden Ruslar zaten kendi aralarında bir birlik oluşturamayan hatta birbirleriyle kıyasıya rekabet halinde bulunan Tatar ve Başkurtlar üzerine yürüyerek bilhassa Türkistan'ın işgalindeki en önemli güzergâh olan Kazakistan bölgesine ulaşmışlardır (Saray, 1990, ss.1-3; Özkan, 2017, s. 91).

Rusların bu denli hızlı ilerleyişi karşısında ilk etapta bir birlik sağlayamayan Tatar, Başkurt ve Kazaklar bir müddet sonra Ruslara karşı güçlerini birleştirmek istemişlerse de başarılı olamamışlardır. Bu başarısızlığın temel sebebi, Rusların Türk toplulukları üzerinde uyguladığı ve onların bir bütün olarak hareket etmelerine engel teşkil edecek kışkırtma politikası olmuştur. Daha sarih bir ifade ile Ruslar kendilerine karşı mücadele eden Türk topluluklarını birbirine düşürerek onların kendilerine karşı zayıf düşmelerini sağlamıştır. Rusların uyguladığı bu politikalar neticelerini vermiş çok geçmeden bölge halkları Rus tabiiyetine girmeye başlamıştır (Ünal, 2010, s.52; Özkan, 2019, ss. 65-82).

Rusların, Türkistan bölgesindeki ilerleyişinin bu denli hızlı ve başarılı olması daha önce de bahsettiğimiz üzere bölgeye gönderilen seyyahların ve devlet görevlilerinin merkeze sunduğu raporlar sayesinde gerçekleşmiştir. Nitekim bölgedeki Rus işgali de bu doğrultuda devam etmiş ve sürekli olarak Türkistan içlerine keşif maksadıyla görevliler gönderilmiştir. Türkistan hanlıkları ve Rus Çarlığ 1 arasında durgun geçen yıllar sonrası Ruslar diğer keşiflerinden müstesna olarak yeni bir elçilik heyetini bölgeye göndermenin hazırlıklarına koyulmuştur. Böylece Romanov hanedanının genç Çarı Mihail Federoviç (1613-1645) tarafından Buhara'da bulunan Rus esirlerinin serbest bırakılması amacı ile İvan Daniloviç Hohlov başkanlığında bir elçilik heyeti 1620 yılında görevlendirilmiştir (Jukovskiy, 1915, ss. 57-58).

İlginç bir kişiliğe sahip olan Hohlov’un; Buhara’ya gönderilmesi, uzun süren tartışmaların ve olay örgüsünün neticesinde gerçekleşmiştir. Rusya'nın daha önce Türkistan bölgesine gönderdiği diğer keşif seferlerine nazaran diplomatik bir tarz barındıran bu heyetin faaliyetleri aslında sadece Rus esirlerinin serbest bırakılması misyonu gibi dar çerçevede düşünülmeyecek kadar önemlidir. Dolayısı ile Hohlov'un nasıl bir süreçten geçerek Rus misyonunun temsilcisi olarak bölgeye gönderildiği, üzerinde durulması gereken bir konudur. Bu nedenle Hohlov'un önceki yıllarda bulunduğu görevlere değinmek yerinde olacaktır.

\section{1. Şah'ın Ülkesinde Esir Bir Rus Elçi}

XVII. yüzyıl Rusya'sının doğudaki komşuları ile kurduğu ilişkiler geniş bir perspektifte düşünüldüğünde oldukça hareketli olmasının yanı sıra karmaşı gözükmektedir. Bilgi alışverişinin oldukça kısıtlı olduğu devirlerde devletler bilgi akışını sağlamak için elçileri ve kervanlar vasıtasıyla tüccarları, muhtelif bölgelere göndererek kendi siyasi argümanlarını belirlemeye çalışmaktaydı. Benzer sebeplerle Rus yönetimi de genişleme sahasında bulunan toplumların gücünü belirlemek, bilinmeyene karşı duyulan korkuyu en aza indirgemek ve uygun pozisyon almak için elçilik heyetlerini bölgeye göndermiştir. Aslında bahsi geçen korkunun tarihsel alt yapısı da uzun müddet yaşanan Türk-Tatar hakimiyetinin yansımasıdır. Elçilerin ülkelerin kaderini belirlemede bu denli mühim olduğu bir dönemde, gönderilecek elçinin nasıl bir karaktere sahip olduğu hangi durumda işe yarayacağı, eğilimleri, çok karmaşık ve hassas konuları müzakere edebilme beceresi elçi tarafindan sunulan verilerin değerlendirilmesinde önemli bir etkendir. $\mathrm{Bu}$ nedenle İvan Daniloviç Hohlov'un çarlığa sunduğu rapor göz önüne alınarak XVII. yüzyılda bilinmeyene yolculuk yapan elçinin bakış açısını belirlemek metnin sağlıklı verilerle inşa edilmesini sağlayacaktır. (Sela, 2013, ss. 69-88). 
İvan Daniloviç Hohlov ismine ilk defa 1600'lerde Safevi Devleti ile kurulan ilişkilere ait yazışmalarda rastlanmaktadır. Safevi Devleti ve Rus Çarlığı arasında elçi teatisinin sıklaştı̆̆ bu dönemde Safevi Şah'1 Abbas adına Rus Çarlığı ile diplomatik temaslar yürütmek üzere Moskova'ya Pir Kulu Bey adlı bir elçi gönderilmiştir. (Aydoğmuşoğlu, 2011, s. 269) Safevi elçisinin Moskova'daki faaliyetleri sonrası Kazan üzerinden ülkesine dönüş yapması öngörülmüştür. Aynı dönemlerde iç ve dış işlerinde kaotik bir ortam hasıl olan Çarlık yönetimi Safevi Devleti ile ilişkilerin daha iyi noktalara gelmesi için Pir Kulu Bey'in Kazan'da karşılanarak ağırlanmasını istemiştir. O dönemde düşük rütbeli bir boyar ${ }^{2}$ olan İvan Hohlov da elçiyi karşılayan heyet arasında bulunmuştur. İran elçisi geldiği dönemde Hohlov, ikinci rütbede bir diplomat olmasına karşın büyükelçilik yetkileriyle donatılmıştır. (Barthold, 2004, s.253).

Hohlov'un bilinen ilk diplomatik görevi sonrası, Rusya'nın iç işlerinin çok karışık olduğu bu dönemde, Çar Boris Godunov tarafından ona, çok farklı zorluklarla karşılaşacağı yeni görevi tebliğ edilmiştir. $\mathrm{Bu}$ göreve göre; Hohlov, Çar'ın hâkimiyetini tanımayan Terek bölgesine bir miktar asker ile gidecek ve orada düzenin yeniden tesis edilmesini sağlayacaktı. Hohlov'un bu yeni görevi oldukça tehlikeli olduğunu gibi karmaşık ilişkiler ağını da barındırmaktaydı. Dolayısıyla Hohlov'un görevinin iyi anlaşıması için Moskova'da cerayan eden olaylar dizisinin iyi anlaşıması gerekmedir. Nitekim Moskova'nın Lehler tarafından işgal edildiği bu dönemde Rus taraftarları Lehlerle Moskova'da çatışma içerisindeydi. Ayrıca Kazakların da Lehlerle Moskova'da çatışmaları devam etmekteydi. Bu süreçte Novgorod'da bulunan Knez Dmitri Pojarski, Moskova'y1 temizlemesi için seçilmişti (Riasanovsky 2011, ss. 173-174). Ancak Pojarski'nin ordusunun Moskova'ya yaklaştığını duyan Kazaklar telaşlanmıştır. Pojarski'yi ile anlaşamayan Kazaklar hatta daha önceleri onu öldürmeye teşebbüs etmişlerdi. Bu nedenle onun intikam hissiyle hareket edeceğini düşünen Kazaklar, Moskova'yı terk etmeye başlamıştır. Moskova'yı terk eden Kazaklar arasında ataman ${ }^{3}$ Zarutski, Marina Mnişek $^{4}$ ve oğlu da vardı. Astarhan'a gitmeyi kararlaştıran Zarutski, Rus hâkimiyetinin yeni tesis edildiği bu bölgede Safevi Şah'1 Abbas'1n da desteğini alarak bir Kazak devleti teşekkül etmek istiyordu (Kurat,1999, ss. 208-209). Rus yönetiminden memnun olmayan Kazakların kendisini destekleyeceğini düşünen Zarutski, burada kısa sürede bir Kazak yönetimi kurdu. Bu durumdan haberdar olan Moskova yönetimi, Don ve Terek boyundaki Kazaklara hediyeler göndererek onları kendi yanına çekmeye çalışmış ayrıca Astarhan'a da bir sterlets (tüfekçi) kuvveti göndermiştir. Aslında bu süreçler gerçekleşmeden önce Rus yönetimi Voyvoda İvan Golovin ile Hovlov'u bölgeye göndermiştir. 1606 yllında Terek ve Astarhan'da bulunduğu dönem hakkında yönetimi bilgilendiren Hovlov, buradaki halkın Çar'a biat etmediğini bildirmiştir. Yani Zarutski'nin Astarhan'a geldiği dönemde zaten Rus hâkimiyeti bölgede tam tesis edilememiştir. Hohlov'un maiyetinde bulunan kardeşi Nikolay da hapse atılmış, bir yıl boyunca işkence görerek öldürülmüsstür. Hatta onun vücudu Astarhan'da sergilenmiştir. Hohlov da bu kargaşa döneminde hapishaneye atılmıştır. Bu bilgilere dayanarak Hohlov'a Çar tarafından verilen diplomatik görevin oldukça zor ve tehlikeli olduğunu söylemek mümkündür (Veselovskiy, 1891, ss. 50-51).

Zarutski’nin kurduğu Kazak yönetiminde tutsak olan Hohlov, nitelikli kadrosundan yoksun Kazak atamanının kısa sürede dikkatini çekmiştir. Zira kendi yönetimine destek olması için İran Şahı'ndan yardım talep etmek isteyen Zarutski, Hohlov'u kendi adına İran'a göndermeyi kararlaştırmıştır. Çok geçmeden de 1613 yılında Şah Abbas'a elçi olarak gönderilmiştir. Bu gelişmelerden sonra Hohlov için işler daha karmaşık hale gelmiş ve kendisi Rus Çarlığı tarafından hain ilan edilmiştir (Veselovskiy, 1891, s. 51).

\footnotetext{
${ }^{2}$ Rus Çarlığında nüfuzlu zümrelere, asil ailenden gelen soylulara ve toprak sahiplerine verilen unvan.

${ }^{3}$ Rus Çarllğında Kazak birliklerini komuta eden üst rütbeli askerlere verilen unvan.

${ }^{4}$ Polonya aristokratlarından olan Marina Mnişek, Katolik kişiliğiyle bilinmekte olup Rus Çarlığı'nı bir müddet yönetmiş olan Düzmece Dimitri ile 6 Mayıs 1606'da bir evlilik yapmıştır. Bu evlilik Moskova'daki mevcut çatışmaların daha da artmasına sebebiyet vermiştir. (Bkz. Riasanovsky, 2011, s. 167).
} 
Çarlık yönetimi, uç bölgelerde bulunan voyvodaların gönderdiği raporlardan Şah Abbas'ın Zarutski'nin yardım talebini karş1layacağını, bunun karş1lı̆̆ında ise onun Astarhan'ı Şah'a vermeye gönüllü olduğu bilgisini almıştır. Bunun üzerine Rus tahtına geçen Çar I. Mihail Federoviç (16131645) 30 Ocak 1614'te Mihail Nikitiç Tihanov ve Alexis Buharov'u hem taht cülusunu haber vermek hem de Safevi Devleti ile ilişkiler tesis etmek üzere Şah Abbas'a göndermiştir. Tihanov o sıralarda Astarhan, Zarutski'nin elinde olduğu için Hive üzerinden oldukça dolambaçlı yolları izleyerek İran'a gitmek zorunda kalmıştır. İran topraklarına ulaşan elçilik heyeti, Astarhan'da çara muhalif Zarutski yönetimine destek verilmemesi için ricada bulunmuştur (Aydoğmuşoğlu, 2011, s. 271). Rus elçilik heyeti bunun yanı sıra Hohlov'un burada tutsak olduğundan dolayı iadesini talep etmiştir. Ancak Şah Abbas, Rus elçilerini hoş karşılamasına rağmen Hohlov'u maiyetinde tutmaya devam etmiştir. Zarutski'den sonra bir nevi Şah'ın da tutsağı haline gelen İvan Hohlov, Mihail Federoviç'in çar olduğunu öğrendiğinde Şah Abbbas'tan kendisini Moskova'ya göndermesi için ricada bulunmuştur. Ancak şah, Hohlov'un isteğini göz ardı ederek onu Gürcistan ile girdikleri mücadelede Gence'de bırakmıştır. B1 sırada Şah'ın niyeti Hohlov aracılığıyla Rus yönetimiyle münasebetlerde elini güçlendirmektir.

Rus elçiliğinin Safevi Devleti topraklarına vardıkları dönemde Kazakların başkaldırısı Moskova orduları tarafindan bastırılmış ve Astarhan'da yönetim yeniden tesis edilmiştir. Ataman Zarutski ise bölgeden kaçmış ancak kısa sürede yakalanarak Moskova'da idam edilmiştir. Tihanov ve maiyeti haliyle bu gelişmelerden hemen haberdar olamamışlardır (Barthold 2004, s. 253).

Şah Abbas, Rus elçileri Tihanov ve maiyetindekilerin şerefine yapılan kutlamalara Hohlov'u da davet etmiştir. Şah'ın hemen yanında bulunan Hohlov, Rus elçilik heyetine karşın daha üst mertebede tutulmuştur. Haliyle bu hareket Rus elçilik heyeti tarafından hoş karşılanmasa da itiraz edememişlerdir. Şah Abbas, bu durumu diğer elçiler geldiğinde de tekrarlamıştır. Hatta Şah'ın Rus elçisi Brehov'u kabulünde Hohlov da davet edilmiş ve İvan Brehov'dan yüksek bir yere oturtulmuştur. Rus elçisi ise kendilerini Rus Büyük Knezi Mihail Federoviç'in yolladığını, Hohlov'un ise Astrahan'dan yollandığını; onun kendilerinden yüksek bir yerde oturmasının nahoş olduğunu ve elçilik kaidelerine uygun düşmediğini söylemiş̧ir (Veselovskiy, 1891, ss. 53-54). Şah Abbas ise Hohlov'u çara karşı arabulucu olarak kullanmayı amaçlamıştır. Onun geri iadesi konusunda şah, Rus elçisi Tihonov'a:

Siz, arkadaşlarınız ve elçileriniz İvan Hohlov'u rahat bırakın ve kardeşim Mihail Federoviç'e; İvan Hohlov ve arkadaşları benim dostluğumu kazandılar, onların günahları benden dolayı oldu ve kardeşim Mihail'e eskiden olduğu gibi onları kendi emrine alır mıydı diye yazılı olarak bildirmenizi emrediyorum. Kardeş bildiğim bu kişi insanların yararınadır. Yirmi yıl süren savaş Moskova Devleti'nde pek çok insanının ölümüne neden oldu ve kardeşim çarın asker sayısı da azaldl.

Şah Abbas, Hohlov'un affedilmesinin yanı sıra Moskova'nın Safevi yönetimine karşı durabilecek bir gücünün de olmadığını ima etmiştir. Bunun üzerine kendisine verilen talimatnamede Hohlov'un cezalandırılması konusunda inisiyatif kullanabilmesi yer alan Tihanov, şahın isteğine şöyle cevap vermiştir:

İvan Hohlov ve arkadaşları Astrahan'daki Zarutski'nin yanında kendi iradeleri dışında bulunmaktalar, ancak onlar hırsız İvaşka Zarutski ve Marinka'nın yanında kendi istekleri ile bulunsaydılar dahi onların Rus Devletine ve büyük yöneticilerimize karşı işledikleri suçlar hoş görüsü, iyi niyeti ve dürüstlügü; çarliğımızın iyi niyet ve hoşgörü temelindeki geleneklerine göre onların bütün suçları verilecek; siz kardeşi yüce Abbas Şah için idamları emir olunmayacak; yüz kızartıcı suçlarından dolayı çarlık herhangi bir ceza kesmeyecek dahası onların bu yaptıkları artık hiçbir durumda hatırlanmayacaktır. Ve siz yüce hükümdar Abbas Şah, biliniz ki Moskova devletimiz, evet, yirmi yıldır süren bir kargaşa içinde pek çok savaşçısını kaybetti lâkin; onların yerini alacak pek çok insan da doğdu. Savaş olmadığ zaman Tanrı kendi öfkesini yolluyor, insan nüfusu azallyor ama onların yerini alacak başkaları doğacaktır ve devlet bu insanlarla işlerini

Turkish Studies - Social, 15(1) 
yürütecektir. Zira bundan sonra yüce devletimizin yöneticileri ve Rus Büyük Hükümdarı Mihail Federoviç'in her şeye gücü yeten kudretli yönetimi vardır ve bilge bir zekaya sahip askerleri çoktur (Veselovskiy, 1891, ss. 54-55).

Rus elçilerinin tutumundan sonra Şah Abbas artık Hohlov ile diğer elçileri eşit mertebede tutmaya başlamıştır. Onları gümüş süslemeli çift kaftan ile donatmıştır. Rus elçilerine 156 ruble veren Şah, Hohlov'a 30 ruble vermiştir. Nihayetinde ise 28 Ocak 1615 yılında Tihanov, Brehov ve Buharov ile Hohlov, şahın görevlendirdiği Fulat (Polad) Bey ile Rusya'ya dönmek üzere yola çıkmışlardır. Bu elçilerin Moskova'ya ulaşması sekiz ay sürmüştür (Veselovskiy, 1891, s. 55).

Şah Abbas'ın gözetimi altından kurtulan Hohlov, Moskova'ya ulaştı̆̆ında çarın emriyle nezarette tutulmuştur. Moskova yönetimi Hohlov'un İran'da casusluk yaptığını düşünüyordu. Hohlov ise yaşananların kendi iradesi dışında gerçekleştiğini iddia etmiştir. Nitekim Hohlov'un yakın arkadaşı Vasilinin, Astarhan'ın Zarutski'den kurtuluşundaki büyük emeği hatırına Hohlov kefaletle serbest bırakılmıştır. Zaten kısa süre sonra da kendisinin Kazan'a gitmesine izin verilmiştir (Veselovskiy, 1891, s. 56).

\section{Kaos ve İstikrarsızlık Devrinde Elçi Olmak}

Kaynaklarda Hohlov'un Kazan'da ne gibi işlerle uğraştığından bahsedilmemektedir. Ancak 1620 yılında Çar Mihail Federoviç tarafından kendisine önemli bir diplomatik misyon verilmiştir. Rus Çarlığı adına Buhara'da elçilik faaliyeti yürütülmesi istenen Hohlov, artık asilzadeliğe yükselmiş ve Daniloviç unvanını kullanmaya başlamıştır. Elbette bu görev için en iyi seçim Hohlov değildi. Zira Hohlov'un uzun süre İran'da kalması, casusluk ile suçlanıp kefalet ile serbest bırakılması onun farklı temaslar içerisinde bulunabileceği şüphelerini kuvvetlendirmekteydi. Ancak onun uzun süre İran'da kalması Türkistan halkları ile kurulacak ilişkilerde ona önemli deneyim kazandırmıştı. Dolayısıyla Rus Çarı onun bu tecrübesinden yararlanmak istemekteydi (Veselovskiy, 1891, s. 57).

Hohlov'a tevdi edilen bu yeni elçilik görevi uzun süredir Rus Çarlığı ile ilişki kurmak isteyen Buhara Hanlığından gelmiştir. 1619'da Buhara'da İmamkulu Han (1611-1642) Rus Çarlı̆̆ ile ticari ilişkileri geliştirmek üzere Âdem Beg (Adambay) adındaki elçisi ile Moskova'ya bir mektup göndermiștir. Bu mektupta Rusya'nın tamamının hükümdarı Büyük Knez Çar Hazretleri Mihail Federoviç'e, Rusya'nın büyük hükümdarları ile Buhara'nın eski hükümdarları arasındaki dostluk ve sevgi bağlarını hatırlatmak için eski atalarının arasındaki var olan iyi ilişsiler ve iki halk arasındaki serbest ticaret yapılabilmesini talep etmiștir. Ayrıca hükümdara Kırım ve Nogay halkından çok fazla kişiyi esir aldıklarını ve onları kendi ülkesi Buhara'ya getirdiklerini, Rusya'nın tümünün hükümdarı Büyük Knez Mihail Federoviç’in sadece elçi veya güvenilir adamını yollamasıyla bu esirleri elçilerle birlikte Moskova'ya yollayabileceğini bildirmiştir. Buhara yönetimi, çardan iyi adamlarını yollaması, kendisini tanımasını ve ülkesiyle ilişki kurulmasının Rusya'nın işine yarayacağını ifade etmiştir. Ayrıca Buhara elçisi Âdem Beg'in bölgede tutulan Rus esirlerin serbest bırakılacağı sözünü iletmesi, Rusya'nın bu ilişkileri tesis etmesi için bir diplomatik misyon oluşturmasına sebebiyet vermiştir (Jukovskiy, 1915, ss. 14-15). Nitekim Hohlov'un ilk ciddi elçilik faaliyeti de bu olay örgüsü neticesinde gerçekleşmiş, tekrar ülkelerine gitmek üzere Moskova'da bulunan Buhara ve Hive elçileri ile Buhara'ya gönderilmek üzere hazırlıklara başlamıştır (Barthold 2004, s. 253).

23 Haziran 1620'de Çar Mihail Federoviç'ten Kazan'da bulunan Hohlov'a görevlendirme talimatnamesi ulaşmıştır. Bu görevlendirmeye göre;

Rusya'nın tümünün hükümdarı Çar Büyük Knez Mihail Federoviç'ten Ivvan Hohlov'a... Boyarlarımızdan olan senin ve Voyvoda Knez Boris Mihailoviç Lıkov ve maiyetindekilerin Buhara Hanlı̆̆ında elçilik görevine tarafimızca atandı̆̆ınızı bildiririz. Göndermiş olduğumuz mesajı Buhara'ya İmamkulu Han'a iletmek için yola çıkmanı emredilmiştir. Sizinle birlikte Tatar tercüman İvan Tırkov, çevirmen Semeyko Gerasimov da Buhara'ya gitmek üzere 
görevlendirilmiştir. Buhara'ya Buharalı elçi Âdem ile birlikte gitmelisiniz. Emrimiz uyarınca Âdem, Âdem 'in kardeşi, maiyetindekiler, Moskova'dan Kazan'a gitmek için tercüman İvan Tırkov ve çevirmen Semeyko Gerasimov ile yola çıkmıştır. Görevinizde nelerden sorumlu olduğunuz konusu İvan Tirkov ile yollanan bir emirnameyle size belirtilmiştir. Tercüman Ivan Tirkov, çevirmen Semeyko Gerasimov, Buharalı elçi Âdem Kazan'a geldiklerinde; Voyvoda Knez Boris Mihailoviç Lıkov ve arkadaşları boyarımız olan size gelecekler ve Kazan'dan yola koyulacaksınız. Emirnamemizi Ivan Tırkov'dan alacak ve Buhara Hanı Imamkulu'nun huzuruna çıkacak ve ilişkileri size verilen emirnameye göre yürüteceksiniz. Sizin, Buharalı elçi Âdem'in, kardeşinin ve onun maiyetindekilerin, tercümanın, çevirmenin yola çıkışı hakkındaki talimatlar Kazan'a ve bundan önce de boyarlarımıza, voyvodalarımıza ve Knez Boris Mihailoviç Lıkov'a konu ile ilgili emirnamemiz Astrahanlı Mark Drozjny ile yollanmıştır. Voyvodalarımızın bir an tereddüt etmeden Hohlov'u gitmekte serbest birakmaları talimatları verilmiştir (Veselovskiy, 1891, ss. 59-60; Hilkova, 1879, s. 389).

Hohlov'a verilen talimatnameden de anlaşılacağı üzere, Moskova'ya çağrılmadan Kazan'da kendisine görev seromoni yapılarak Buhara'ya doğru yola çıkacaktır. 13 Temmuz'da görevi tebliğ edildikten bir hafta sonra Hohlov, Buhara'ya doğru yola çıkmaya hazır hale gelmiştir. Ancak Astarhan üzerinden Hazar Denizi ve orayı geçtikten sonra Hive Hanlığ 1 topraklarından geçmesi gerektiğini bilen elçi, bu zorlu yolculuğa çıkmadan önce çara taleplerini iletmiştir. $\mathrm{Bu}$ talepnameye göre Hohlov çardan bu görev karşılığında Kazan kasabalarından biri olan Nijegorod'daki malikânenin kendisine bahşedilmesi ve orada yerleşim birimi olmayan bir bölgeden toprak verilmesini istemiştir (Veselovskiy, 1891, s. 60). Çar tarafindan Hohlov'un bu istekleri uygun görülmüş ve onun ilk ciddi elçilik misyonu böylece başlamıştır.

\section{Hohlov'un Buhara Misyonunun Çerçevesi, Nakaz ve Maiyeti}

Rus Çarlığı diplomatik ilişkilerde bulunmak üzere görevlendirdiği elçilere nakaz adlandırılan yazılı talimatlar vermiştir. Bunlar Türkistan bölgesine giden Rus elçilerinin uyması zorunlu kurallar olup diplomatik adap, çarın unvanlarının doğru kullanılması, seyahat rotası, diplomatik misyonun hedefi ve bunları nasıl başarabileceklerine dair bilgiler içermektedir. Elçiler bu talimatnamelere uymak zorundaydılar yani bunların dışında kendi düşüncelerine göre hareket etmeleri yasakt1. (Bohlen, 1966, ss. 344-345). Hohlov'a verilen talimatnamede belli kurallar çerçevesinde hareket etmesi ve sadece çar ve Buhara hanı arasında pasif bir konumda hareket etmesi emrediliyordu. Eğer elçi, han veyahut başka bir grup tarafından sorgulanırsa Büyük Çar Mihail Federoviç'in bir elçisi olduğunu belirtmeliydi. Ayrıca çar tarafından verilen hediyeler direkt olarak hana ulaştırılmalı kesinlikle bir aracı kabul edilmemeliydi. Buhara hanının huzuruna çıktığında önünde başka bir ülkenin elçisi olmamalı ve han çarın sağlığını sorarak iyi niyetlerini iletmeliydi. Eğer bu diplomatik ritüeller uygulanmıyorsa huzurda kalmamalıydı. Aslında çarın istekleri erken dönem modern diplomasinin bir parçasıydı ve bu durum Ruslarla sınırlı değildi. (Hilkova, 1879, s. 425).

Hohlov'a verilen talimatnameye (nakaz) göre ona yüklenen misyonu dörde ayırabiliriz. Bunlardan ilki diplomatik ritüellerin doğru bir şekilde uygulanması sağlanarak çarın prestijini korumak; ikincisi Rus Çarlığındaki iç karışıklık döneminin tamamen bittiğini ilan etmek; üçüncüsü Buhara'da bulunan Rus esirlerinin kurtarılmasını sağlamak; son olarak ise ticari ilişkilerin gerçekleştirilmesi olmuştur. Genel manada düşündügümüzde Hohlov'un faaliyetleri bu dört ana gündem maddesi etrafinda dönmektedir. Elçinin bu istekleri ne kadar gerçekleştirebildiği ve kurduğu ilişki ağı bu çalışmanın ana problematiğini oluşturmaktadır (Hilkova, 1879, ss. 426).

Hohlov'un uzun müddet bölgede bulunduğu düşünüldüğünde bu talimatnameleri kısmen yerine getirdiği tespit edilmektedir. Zira bu dönemdeki diplomatik raporlar genelde heyetler döndüklerinde sorgulama usulü ile ortaya çıkmaktadır. Daha açık bir ifade ile Rus diplomatik görevlilerinde hala günlük veyahut kişisel günlük tutma tecrübesi gelişmemiştir. Sadece yol boyunca tuttukları karmaşı notlar sorgulama esnasında bazı cevapların kavramsal çerçevesinin 
daha rahat çizilmesine yaramıştır. Nitekim Hohlov'un Buhara hakkında verdiği bilgilerin yüzeysel olması bu durumu kanıtlar niteliktedir. Aynı dönemde Avrupa seyyahlarının doğa üzerinden insan çeşitliğinin keşfi ile hareket etmelerinin aksine Rus diplomatik misyonları raporlarında sadece verilen görevler etrafında bilgi sunmuşlardır. $\mathrm{Bu}$ nedenle onların raporlarında yoruma dayalı ifadeleri bulmak zordur. Bunların yanı sira Hohlov'un yol boyunca tuttuğu notların ve talimatnamelerin bir kısmını geçiş güzergâhında bulunan Ürgenç hâkimi Habaş’tan korktuğu için gömmesi ve daha sonra bulamaması, elde ettiği bilgilerin kısmen yüzeysel olmasına neden olmuştur (Sela, 2013, s.74).

Orta düzey bir asilzade olan Hohlov, diplomasiye tam anlamıyla aşina olmasa da daha önce başarısızlıkla neticelenen elçilik faaliyetlerinin içerisinde bulunması ve tutsak hayatı yaşaması onun bölge halkıyla ilişki kurma tecrübesini son derece arttırmıştır. Nitekim daha önceki Rus görevlilerin aksine anlatısında Türkistan topluluklarının birbiri arasında ilişki dinamiklerine değinmesi onun raporlarını değerli k1lmaktadır 5 .

1620 'de Buhara'ya gitmek üzere yola çıan Hohlov'u güzergahı boyunca pek çok zorluk bekliyordu. Bu nedenle Rus elçisi Hive ve Buhara arasındaki yolda karşılaşacağ 1 muhtemel zorluklar hakkında bilgiler toplamaya çalışmıştır. Elçi maiyetinde çevirmenler, korumalar, tüccarlar ve muhtelif görevliler mevcuttu. (Hilkova, 1879, ss. 389,410,411,443) Ancak Hohlov'un raporları maiyetindeki görevlilerin isimleri konusunda oldukça ketumdur. Hatta elçinin bölgede bulunduğu süre zarfında kurduğu ilişki ağında bazı Buharalı memurların unvanlarını ve isimlerini karıştırması bölge hakkındaki tecrübesi olmasına rağmen vasıfsızlığını gözler önüne sermektedir. Yine de elçinin raporlarında bazı ana karakterler göze çarpmaktadır. Bunların en önemlisi elçilik için hayati bir pozisyonda olan İvan Tırkov ve Semeyka Gerasimov adlı tercümanlardı. Bu dönemde Rus Çarlığ 1 komşuları ile kurduğu etkileşimde yabancı dil beceresine sahip diplomatik misyon oluşturmakta zorluk çekmekteydi. Bu nedenle genelde Türkistan bölgesine gönderdiği elçilik heyetleri içerisindeki tercümanlar ya bölgede uzun süre kalmış Rus esirler ya da Ruslaştırılmış Tatarlardan oluşmaktaydı. İvan Tırkov da bu Tatarlardan biriydi (Khodarkovsky (2002), 70-73). Hohlov'un raporlarından kendisine üst düzey elçilerin de eşlik ettiğini belirlemekteyiz. Bunlardan biri Buhara Hanlığının elçisi Âdem Bay diğeri ise Hive elçisi Rahim Kulu'dur. Hohlov'a dönüş yolunda ise Hive yöneticisi İlbars Sultan'ın elçisi Makhtamanbaydı eşlik etmiştir (Hilkova, 1879, ss. 389,406,415). Türkistan Hanlıklarının, Rus Çarlığına gönderdiği elçilerin üst düzey olduğu düşünüldüğünde onların nazarında çarlığı konumlandırabilmekteyiz. Peki, Rus Çarlığı nezdinde hanlıkların pozisyonu neydi ve Hohlov ne derecede bir elçiydi. Bu sorunu yine Hohlov'un raporlarından yola çıkarak belirlemek veyahut bir fikir yürütmek mümkündür. Zira Buhara hanı İmamkulu'ya gönderilen elçinin hediye olarak hana sunacağı akdoğanların ${ }^{6}$ sayısı burada kilit rol oynamaktadır. Zira çar İmamkulu'ya dört akdoğanı hediye olarak sunarken aynı dönemlerde 1618 'de Safevi Şahı'na Rus elçisiyle daha fazlasını hediye etmiştir. Bu süreç Türkistan Hanlıkları ve Safevi Devleti'nin aynı pozisyonda olmadığını gösterdiği gibi Hohlov’un üst düzey bir elçi olmadığını da kanıtlamaktadır (Knighting, 2008, s. 25).

\section{Hohlov'un Yolculuğu}

Hohlov'un raporunda Buhara seyahatinin ilk safhası hakkında bilgi mevcut değildir. Ancak onun resmi raporlar dışında daha sonra çara hitaben yazdığı talepnameden 1 Eylül 1620'den önce Astarhan'dan ayrıldığını belirlemekteyiz. Bu süreçten sonra Hohlov daha önce defalarca geçtiği

\footnotetext{
${ }^{5}$ Hohlov'dan önce bölgeye gönderilen Nikitin'in gözlemlerindeki monotonluk ve kısıtlı anlatım göz önüne alındığında elçilik heyetinin sunduğu rapordan doğrudan Rus otoriteleri ilgilendiren spesifik bilgiler ve bölge hakkında detaylı anlatım göze çarpmaktadır (Bkz. Nikitin, 2018).

${ }^{6}$ Değerli bir yırtıcı kuş türü olan akdoğanlar, dönem itibariyle Rus Çarlığı ve Türkistan Hanlıkları arasında hediyeleşme aracı olarak sık sık kullanılmıştır. Hohlov'dan sonra Rus Çarlığı tarafından elçi olarak Buhara ve Hive'ye gönderilen Pazuhin kardeşlerin de hediyeleşmelerde akdoğan kullandığı bilinmektedir. (Bkz. Burton, 1997, s. 147-148; Karakulak, 2019, s. 1618).
}

www.turkishstudies.net/social 
Astrahan'dan ilerleyerek Hazar Denizi'ni geçmiş, geceleyin gemileri Hazar kıyılarına çarpmıştır (Knighting 2008, ss.110-112). Elçi ve maiyetindekiler yaşadıkları kaza neticesinde nerede olduklarını tam olarak bilmiyorlardı. Ancak bu saha Türkmenlerin hâkimiyetindeydi. (Lunin, 1988, s. 36). Zaten kısa süre sonra Türkmen göçerler kendilerini bulmuş ve iki grup arasında bir çatışma hâsıl olmuştur. Türkmenlerle baş edemeyeceğini anlayan Hohlov, Hive elçisi Rahim Kulu'yu onlarla müzakere etmek için göndermiştir. Rahim Kulu Türkmenlere yalan söyleyerek, Hohlov'un Rus Çarlığı tarafından Hive hanına gönderilmiş üst düzey bir elçi olduğunu belirtmiştir. (Hilkova, 1879, s. 393). Türkmenler Hohlov'un Buhara elçisi olduğunu bilseler tereddütsüz onu öldürecekleri bir gerçekti. Zira aynı dönemlerde Buhara Hanlığı ve Türkmenlerin arasındaki ilişkiler oldukça gergindi. Bu nedenle Hive elçisi böyle bir yalana başvurmuştu. Ancak Türkmenler bu yalana hemen kanmamış elçilik heyetini iki gün boyunca sorgulamıştır. Hatta Hohlov ve ekibi kendilerini Türkmen saldırılarından korumak için küçük bir istihkam inşa etmişlerdir. Hohlov'un verdiği bilgilere göre kendilerine saldıran Türkmenlerin Ruslar hakkında bir bilgisi yoktur (Hilkova 1879 ss. 389-390). Zira Ürgenç’ten gelen elçiler ve tercümanlar Türkmenlerin bir kısmıyla ittifak kurmayı başarabilmiş diğer Türkmenlerle çatışmalar devam etmiştir. Hohlov ve maiyeti yirmi günlük kuşatmadan sonra yollarına devam edebilmiştir. Ancak kısa müddet sonra onları takip eden Türkmenler tarafindan Rus elçilik heyeti pusuya düşürülmüş hatta Hohlov saldırganlardan birini öldürmüştür. Türkmen bozkırlarında sıkışıp kalan Hohlov ve yol arkadaşları bu kargaşadan kurtulmak için Türkmenlerle antlaşma yoluna gitmiştir. Hohlov ve maiyetindekileri kuşatan saldırganlar ölülerine karşılık para veyahut elçilik heyetinden ölü sayısı kadar köle verilmesini istemiştir. Bunun üzerine Hohlov deri, bıçak, elbise gibi yanlarında bulunan eşyaları Türkmenlere vererek serbest bir biçimde hareket etme özgürlüğüne kavuşmuştur (Hilkova 1879 ss. 391-393). Hohlov öncesi ve sonrası bölgeye giden Rus resmi temsilcilerinin benzer saldırılara uğradıkları bilinmektedir. Hatta neredeyse Hohlov'dan bir buçuk asır sonra Karl Miller öncülüğünde Taşkent'e giden Rus kervanına da aynı şekilde saldırıya uğramış ve kervanda bulunan bazı tüccarlar öldürülmüştür (Abduraimov, 1995, ss. 87-93).

\section{Hohlov'un Ürgenç'teki Faaliyetleri}

Buhara'ya ulaşmak için Hive topraklarından geçmek zorunda olan Hohlov, Ürgenç'e uğramak zorundaydı. Türkmen saldırılarından verdikleri rüşvet ile kurtulmayı başaran elçilik heyeti üç gün boyunca yola devam ettikten sonra Ürgenç şehri sınırlarına ulaşmışlardı. Burada onları Hive Han'1 Arap Sultan'ın oğlu Habaş Sultan'ın yavasulu karşılamştır (Hilkova, 1879, s. 392). Rus elçilik heyeti Ürgenç şehri sınırlarına giriş yaptıklarından itibaren göz altına alınmış ve kendilerinden sürekli olarak hediye adı altında haraç alınmıştır. Bu süreç onların Ürgenç'te nasıl bir muamele ile karşı karşıya kalacaklarını da gösteriyordu. (Hilkova 1879, s. 398-399). Zaten çok bir süre geçmeden Ürgenç yöneticilerinden Hive Han'1 Arap Muhammed'in oğlu Habaş Sultan bir memurunu göndererek elçilik heyetine bir koyun ve az miktarda arpa vermiş karşıllı̆̆ında ise Habaş Sultan'a hediye sunması istenmiştir. Eğer elçilik heyeti hediye sunmaz ise tutuklanacaklarını söyleyerek onları tehdit etmiştir (Hilkova, 1879, s. 393). Hatta Buhara hanına verilmek üzere çar tarafindan gönderilen akdoğanlar Habaş Sultan tarafindan bizzat talep edilmiştir. Ürgenç'te herhangi bir diplomatik görevi bulunmayan Hohlov, ilk başta akdoğanları vermek istemese de zorla alınacağını bildiğinden Habaş Sultan'ın huzuruna çıkmadan önce tercümanı Gerasimov aracılı̆̆ı ile onları sultana göndermiştir. Bir müddet sonra da Habaş Sultan'ın huzuruna kabul edilmiştir ${ }^{8}$

\footnotetext{
${ }^{7}$ Türk-Mogol devletlerinde sıkça karşımıza çıkan ve Buhara ve Hive devlet teşkilatında da gördüğümüz düşük rütbeli asker olan yavasullar, çok sayıda görevi yerine getirmekle mükellefti. Bunlar arasında haberci, vergi tahsildarı, yöneticilerin gönderdiği hediyeleri dağıtımını sağlama, elçilik heyetlerini karşılama, Han ile şehzadeler arasında ilişkileri düzenleme, Han’a kabulleri sağlama gibi görevleri ifa etmekteydi. (Bkz. Burton, Hatunoğlu, 2017, s.491).

${ }^{8}$ Hohlov, diplomatik nezaket gereğince hanın huzuruna çıktığında yün, sincap kürkü, deriler, şarap ve tabaklardan oluşan bir hediyeyi ona takdim etmiştir. Hive hanı hediyelerin üst düzey olmamasını Çar'ın iyi dileklerinin azlığı olarak saymış ve kabul etmede çekimser kalmıştır. Ayrıca hoşnutsuzluğunu kendisi de Hohlov'a ifade etmiştir. Hatta onlara oldukça çeşidi az yemek ikram etmiştir.
}

Turkish Studies - Social, 15(1) 
(Hilkova, 1879, s. 393). Hohlov'un seyahatindeki bu ilk diplomatik temas tefrişat kurallarının uygulanması ile başlamış, Habaş Sultan, çarın sağlığını sormuş, elçinin elini tutarak samimiyet göstermiş ve çarın kendisine bir mesajının olup olmadığını iletmiştir. Hohlov bu diplomatik ritüelleri takiben kendisinin Buhara hanına gönderildiğini, çarın Ürgenç'ten herhangi bir talebi bulunmadığını ve kendisinin haksız yere göz altına alınmasını proteste ederek sözlerini bitirmiştir. Hohlov'un sorularına cevap vermeyen Habaş Sultan kendisine ekmek, kavun ve balık ikram ederek Buhara'ya gitmelerini yasaklamıştır (Hilkova, 1879, s. 394).

\section{Hohlov'un Hive'deki Faaliyetleri}

Hohlov ve maiyetinin Ürgenç'teki göz altı süresi Habaş Sultan'ın kendilerini Hive Han'1 Arap Muhammed'in yanına göndermesiyle son bulmuştur. Ancak Habaş Sultan, Rus elçilik heyetine ne erzak ne de bir araba tahsis etmiştir. Tüm bu gelişmelerin üstüne Ürgenç'teki bazı memurları Habaş Sultan'ın emri olmasına karşın Hohlov'un yolunu kesmiş ve ondan bir miktar rüşvet alarak yola devam etmelerine izin vermiştir (Hilkova, 1879, s. 394). Rus elçilik heyeti Hive'ye yaklaştıklarında Arap Muhammed'in yavasulu onları karşılamış ve iaşelerini sağlanmıştır. Habaş Sultan'dan ziyade babası Arap Muhammed'in tavrı elçilik heyetini daha çok memnun etmiştir. Çok geçmeden han, Hohlov'u huzuruna kabul etmiştir. Hanın küçük oğlu Afgan Sultan da bu görüşmede yer almıştır. Hohlov ve maiyeti on iki gün boyunca Hive'de tutulmuşlardır. Daha sonra Arap Muhammed ile yapılan müzakereler neticesinde hana verilen hediyeler karşılığında şehirden çıkışlarına izin verilmiştir (Hilkova, 1879, s. 396, 416). Ancak, han izin vermesine karş1 onun yavasulu Hohlov'dan rüşvet talep ederek şehirden çıkışına izin vermemiş onu iki gün gözaltında tutmuştur. Bunun üzerine Hohlov ödeme yapmayı reddetmiştir. Hohlov'un tercümanı İvan Tirkov devreye girerek şehrin önde gelenlerinden yardım istemiş ancak o da bir sonuca ulaşamamıştır. Nitekim Hohlov, yavasula rüşvet vermek zorunda kalmıştır (Hilkova, 1879, s. 396). Tüm bu ödemelere rağmen Hohlov ve heyeti Arap Muhammed Han'ın iki oğlu Şerif (Şizrif) Sultan ve Ebu'l Gazi Sultan tarafından ölümle tehdit edilmiştir. Hohlov, han tarafindan kendisine verilen geçiş iznini göstermesine rağmen ikna olmayan hanın oğulları, Hohlav'dan geçiş vergisi ve hediye istemişlerdir. Arap Muhammed hanın bir diğer oğlu olan ve elçilik heyetinden belki de tek beklenti içerisine girmeyen Efal Sultan araya girmesine rağmen Hohlov, hediye ve rüşvet vermeden yoluna devam edememiştir. Nihayetinde Hohlov, bir kez daha Hivelilere karşı mağlup olmuştur (Hilkova, 1879, ss. 416, 396). Hohlov ve ekibi tüm bu tehlikeyi atlatmasına rağmen kısa süre sonra Hiveliler Rus heyetini seksen kişilik birlikle takip etmeye başlamıştır. Rus elçilik heyeti şehirden uzaklaşmaya başlayınca takip son bulmuş Buhara önlerine ulaşabilmişlerdir (Hilkova 1879 s. 400).

\section{Hohlov'un Buhara'da Faaliyetleri}

Hive topraklarından kaçarak kurtulan Hohlov ve maiyeti Buhara'ya yaklaşık on mil uzaklıktaki Haydarabad şehrinde dört gün boyunca konaklamışlardır. (Hilkova, 1879, s. 398). Hohlov, Buhara'ya ulaştı̆̆ında İmamkulu, Kazak Tursun Sultan'a karşı bir askeri sefer düzenlediğinden dolayı Semerkant'ta bulunmaktaydı. Bu nedenle Hohlov ve ekibini hanın yerine bakan Vali Mirza Bik ağırlamış on gün boyunca onların ihtiyaçlarını karşılamışlardır. Heyete koyun, yakacak odun, ekmek ve darı vermişlerdir (Hilkova 1879 s.398). Hohlov, Buhara'da Hive'ye göre daha iyi ağırlansa da hanın yerine bakan vali ve memurlar Hive'de olduğu gibi elçilik heyetinin yanında getirdikleri hediyelere göz dikmişlerdir. Bilhassa Buhara valisi Hohlov'un yanında getirdiği akdoğanları almak için çok çabalamıştır (Hilkova, 1879, ss. 427-429). Hatta Buhara elçisi Âdem Bay bile akdoğanları almak istemiş bunun üzerine Hohlov'un tercümanı ile kavgaya tutuşmuşlardır. Bir süre sonra İmamkulu'nun kuşbeyi Nazır gelerek Hohlov'dan akdoğanları talep ederek onları Semerkant'a götüreceğini söylemiştir. Ancak Hohlov kendisine verilen talimatnameye sadık kalarak akdoğanları İmamkulu'ya kendisinin sunacağını belirtmiştir (Hilkova, 1879, s. 398).

Hohlov, Buhara hanı İmankulu'nun bir müddet daha gelmeyeceğini anlayınca vakit kaybetmeden Semerkant'a doğru yola çıkmıştır. Hohlov beş günlük bir yolculuktan sonra 
Semerkant'a ulaşmıştır (Burton, 1997, ss. 460-461). Burada uzun süre İmamkulu'yu bekleyen Hohlov nihayetinde hanın huzuruna kabul edilmiştir. Bu görüşmede elçilik heyetini oldukça iyi karşılayan han, uzun süredir Rus Çarlığı'ndan elçi gelmediğinden dolayı yakınmıştır. Bunun üzerine Çar'ın iyi dileklerini ileten Hohlov diplomatik teamüller gereği öncelikle Çar'ın mektubunu okumuş daha sonra Buhara Hanı İmamkulu'ya verilmek üzere yanında getirdiği akdoğanlar ve hediyeleri takdim etmiştir. Ancak Çar'ın selamının İmamkulu'ya iletildiği esnada hanın bir saygı gösterisi olarak ayağa kalkmaması hatta Çar'ın mektubunu elçiden ziyade yavasulu aracılığ 1 ile kabul etmesi Hohlov tarafindan diplomatik nezaketsizlik olarak kabul edilmiştir. Elçi her ne kadar hanın bu tavrını kabul edilebilir olarak görmediğini raporlarında ifade etse de sözlerinin hayal ürünü olma ihtimali de yüksektir. Nihayetinde bu protokol işlemlerinden sonra Rus kölelerin bırakılması için müzakereler başlamıştır (Hilkova 1879 ss. 400-402; Türker, 2019, s. 99) Hohlov'a verilen talimatnameye göre Buhara Hanlığında tutsak olan esirlerin sayısı, hangi işlerle meşgul oldukları ve hanın sarayındaki pozisyonları hakkında bilgi toplanması istenmiştir. Ayrıca asilzade ve asker olanların öncelikli olarak kurtarılması ve onların soylu olduklarının fidye fiyatını arttıracağından Buhara'da yöneticilere belli edilmemesi hususunda dikkat edilmesi tembih edilmiştir. (Burton, 1998, s. 348).

Buhara Han'1 ve Hohlov arasında başlayan müzakereler neticesinde İmamkulu, Hohlov'un Rus kölelerin bırakılması için teklif ettiği para ile ancak sekiz kölenin fidyesinin karşılanacağını söylemiştir. Hohlov'a verilen nakaz gereği daha fazla kölenin özgürlüğüne kavuşturulmas1 planlandığından müzakere süreci uzamıştır. Bunun üzerine bu süreç hanın amcası ve aynı zamanda hazine memuru Nadir Diyanbegi ${ }^{9}$ ile devam etmiştir. Hatta Hohlov, Nadir'e altı ruble, tabaklanmış deri ve kumaş1 rüşvet olarak vermiştir. Böylece görüşmeler neticesinde Hohlov öncelikle yirmi yedi esirin serbest bırakılmasını sağlamıştır. Daha sonra kendisi bizzat para ödeyerek toplamda kırk dört Rus esirin özgürlügünü elde etmiştir. Hohlov'un Feodor Velyaminov ve Vasili Boltin adlı esirleri kurtarmak için cebinden yetmiş sekiz ruble ödediği notlarında yer almaktadır (Hilkova 1879 ss. 402-405). Hohlov'un özgürlüklerini satın aldığı esirler arasında asilzade ve soylular dışında kişiler de mevcuttu. Hatta esirlerden birinin görme engelli yaşlı bir kadın olduğunu belirten Hohlov, bazı esirlerin ise uzun süre Buhara'da kalıp Müslüman olduğu için önceki isimlerini bile unuttuğunu ifade etmiştir. Hohlov'un Rus esirlerini kurtarma yönündeki diplomasi başarısı bölgeye giden Rus elçilik heyetlerinin çok azı tarafından gerçekleştirilebilmiştir (Burton, 1998, s. 351).

Hohlov, Semerkant'ta İmamkulu'nun huzurunda bulunduğunda kendisine verilen bilgiler çerçevesinde Rus Çarlığı'nın politik durumu hakkında da hana bazı bilgiler vermiştir. Bilindiği üzere Hohlov görevlerinden birisi de çalkantılı bir dönemden geçen Çarlık yönetiminin sıkıntılı zamanlarının sona erdiğini bildirmekti. Bu nedenle elçi İmamkulu'ya Rus yönetiminin bozkır göçebeleri üzerindeki hakimiyeti tesis ettiğini ve ticari şartların oldukça iyileştirildiğini, Osmanl1 ${ }^{10}$, İran ve diğer Avrupa devletleri ile iyi ilişkiler içinde bulunduklarını belirtmiştir. Bunlara karşın Lehistan-Litvanya'yla düşman olduklarını ifade etmiştir (Sela, 2013, ss. 75).

Hohlov'un tuttuğu seyahat notlarında önemli bir kısım teşkil eden bölüm de Nadir Diyanbegi ile görüşmesi olmuştur. Daha çok Nadir Diyanbegi'nin Hohlov'a soruları ve cevapları etrafında şekillenen görüşme, önemli bilgiler ihtiva etmektedir. Hatta bu noktada Ruslarınkinden ziyade Buharalıların Rus Çarlığı hakkındaki endişe ve merakının son derece fazla olduğu ortaya çıkmaktadır. Anlaşılacağı üzere Buhara Hanlığı o dönemde Rusların bozkır halkları üzerindeki hâkimiyeti üzerinde kesin bilgilere sahip değildir. Bilhassa Nogayların pozisyonu hakkında soruların yoğunlaşması dikkat çekicidir. Zira Hohlov'un da dediği gibi o dönemde bazı sıkıntılar

\footnotetext{
${ }^{9}$ Buhara devlet teşkilatında önemli bir unvan olan Divanbegliği, hazine, mali işler, dış işleri ve diplomasi gibi muhtelif devlet görevlerini de kapsamaktadır. (Bkz. Ükten, 2018, s. 150).

${ }^{10}$ Rus Çarlığı bu dönemde kaotik bir dönem yaşadığından dönemin önemli güçlerinden olan Osmanlı Devleti'nden de destek almak istemiş, 1622'de İvan Gavriloviç Kondırev, 1634'de ise Vasiliy Andreeviç Korobkin elçi olarak İstanbul'a gelmiştir. (Bkz. Teplova, 1891, s 7).
} 
yaşanmış Nogaylar bir müddet bağımsız hareket etmiş ise de Rus hâkimiyeti yeniden tesis edilmiştir. (Hilkova 1879 ss. 404-405). Zaten Hohlov'un bölgeye gönderilmesinin önemli gerekçelerinden biri de Rusya'daki karışıklık döneminin Romanov Hanedanlığı ile artık atlatıldığı ve bozkırda Rus hâkimiyetinin yeniden sağlandığını bölgeye ilan etmektir ${ }^{11}$.

Hanı'n amcası Nadir Diyanbegi, Hohlov'a step bölgeleri hakkındaki bilgileri Nogay köle tacirlerinden aldığını söylemiştir. Ayrıca Kazaklar ile yapılan mücadelede Rus kölelerin kullanıldığını da eklemiştir. Buhara ve bölgedeki siyasi, iktisadi ve askeri durumun oldukça kaotik bir yapıda olduğunu belirten Hohlov, Belh ve İranlıların (Safevilerin) savaş halinde olduğunu, yine Safeviler ile Hint-Türk Devleti (Babürler) arasındaki çatıșmanın devam ettiği bilgisini vermiștir. Hohlov'un notlarında Belh ve Buhara iki kardeș arasında bölünmüș tek bir hanlık olarak anlatılmıştır. Buhara yönetimi Belh üzerinde daha etkin durumda olsa dahi halkın Belh'de küçük kardeşi desteklediklerini söyleyen Hohlov, Buhara ve Taşkent’teki Kazak lideri Tursun Sultan'ın da aralarında çatışma halinde olduğu bilgisini vermiştir. Hatta bu çatışmalarda Buhara ordusu Tursun Sultan'in on bin kadar askerini öldürdüğünü ifade etmiştir. Ancak İmam Kulu'nun bu hareketi halk nezdinde kabul görmedi ve kendisine tepki oluşmasına sebebiyet verdi. Kalmukların Hive'ye yönelik akınlarından da bahseden Hohlov, Hive ve Buhara'nın çatışma halinde olduğunu belirtmiştir (Hilkova 1879 ss. 420-422).

Buhara Hanlığında bulunduğu süreçte bölgenin askeri yeterliliğini de inceleyen Hohlov bölgede silahların oldukça eski olduğunu, demir bir top gördüğünü, askerlerin çoğunluğunun atlı okçu ve mizraklı süvari birliklerinden oluştuğunu, belirtmiştir ${ }^{12}$. Bu süvari birliklerinin yüz bin civarında olduğunu belirten Hohlov, Ürgenç'te ise on iki bin savaşçının olduğunu söylemektedir (Hilkova 1879 ss. 423-424).

Hohlov'a verilen talimatnamelerde bölgede Rus hâkimiyetinin tesis edilmesi için hanların önde gelenlerinin Rus Çarlığının hizmetine girmesini sağlaması da vardı. Başarılı bir elçilik faaliyeti yürüterek Rus esirlerin büyük bir kısmının serbest kalmasını sağlayan Hohlov kendisine verilen bu görevi de başarı ile yerine getirmiş, Hive'nin genç prenslerinden Afgan Sultan'ın çarın hizmetine girmesini sağlamıştır (Vesolovskiy, 1891, sş. 62; Barthold, 2004, s. 53). Buhara'daki diplomatik misyonu sona eren Hohlov 13 Eylül'de şehri terk etmek için hazırlıklara başlamıştır. Ancak bu sırada İmamkulu'nun Semerkant'tan Buhara'ya gelişi nedeniyle Hohlov üç gün daha beklemiştir.

\section{Dönüş Yolunda Habaş ve İlbars Sultan ile Yaşanan Süreç}

Rus elçilik heyeti Buhara'dan ayrıldığında dönüş istikametinde yer alan Hive topraklarında iç savaş vardı. Hive hanı Arap Muhammed, oğulları İlbars ve Habaş tarafindan tahtan indirilmiş ve gözleri kör edilmişti. Hive hanının diğer oğulları Ebul-Gazi, Şerif ve Efal ise Buhara hanına sığınmışlardı. Ürgenç'in yönetimi ise Habaş Sultan'daydı. Bu nedenle Hohlov ve elçilik heyeti dönüş istikameti için Safevi topraklarından geçmeyi uygun gördüler (Koç, 2018, s.584; Barthold, 2004, s.253; Hilkova, 1879, s. 406). Bu sırada Habaş Sultan ve İlbars Sultan bir memur göndererek Hohlov'un Hive topraklarından geçmesini talep etti. Zira Safevi güzergahı hem uzun hem masraflıydı. Ayrıca Habaş Sultan, Hohlav'a güvenli bir biçimde seyahat edebileceği garantisini de vermekteydi. Hohlov daha önce yaşadıklarını bir kenara bırakıp, Habaş Sultan'ın çarın düşmanlığını kazanmak istemeyeceği düşüncesiyle bu teklifi kabul etti. Habaş Sultan'ın adamları Hohlov ve heyetine yol boyunca oldukça kibar davranmışlardı (Hilkova,1879, s. 406). Nihayetinde elçilik 11 Kasım 1621'de Ürgenç'e geldi (Hilkova, 1879, s. 439). Ancak onlar şehre girişleriyle

\footnotetext{
${ }^{11} 1598$-1613 yılları arası Rusya tarihi için oldukça kaotik bir dönemi yansıtmaktadır. Smutnoe Vremia (Karıșıklık dönemi) olarak bilinen ve 1598 'de Boris Godunov'un Moskova tahtına geçişi ile başlayıp 1613'te Mihail Feodoriç'in tahta seçilmesi ve Romanov Hanedanlığının başlaması ile son bulan süreçtir. (Bkz, Riasanovsky. Steınberg, 2011, s. 160).

${ }^{12}$ Buhara Hanlığı'nın askeri teşkilatı hakkında tafsilatlı bilgi için (Bkz. Ükten, 2018).
} 
gözaltına alındılar. Dolayısıyla Hohlov, yine zor bir süreç ile karşı karşıyaydı. Ayrıca Hohlov ve maiyetinin yanında Hiveli memurların dikkatini çekecek mink kürkleri, yünler, elbiseler, deri eşyalar, şarap testileri ve samur kürklerinin bulunması onlar için bir dezavantaja dönüşmüştü. Tüm bu bilgiler birleştiğinde Hohlov'un bölgeden kolay kolay ayrılamayacağı aşikârdı. Zaten Hive hanının oğlu Habaş Sultan hakkında Hohlov'un raporlarında oldukça detay verilmesi de bu durumu açıklamaktadır (Hilkova 1879 ss. 396-397).

Hohlov ve heyeti Buhara'ya gidiş yolunda olduğu gibi dönüş yolunda da Hive hanlığ topraklarında sıkışıp kalmışlardı. Hohlov, Habaş Sultan ve İlbars Sultan'a yaptıklarının çarlık nezdinde iyi karşılanmayacağı iletmesine rağmen durum değişmemişti. Bir müddet sonra Hohlov, Hive'de bulunan İlbars Sultan'ın huzuruna çağrıldı (Hilkova, 1879, ss. 396-398). Hohlov ile İlbars Sultan'ın görüşmeleri esnasında hanın kırk kadar memuru ve danışmanı olan atalı $^{13}$ olarak adlandırılan kişiler mevcuttu (Hilkova, 1879, s. 442-443). İkili görüşmelerde diplomatik ritüeller sonrası İlbars bir elçisini çara göndermek istedi. İlbars'ın bu isteği Hohlov tarafindan kabul edildi. Zaten Hohlov'un Hive sınırları içerisindeyken herhangi bir talebi kabul etmemesi mümkün gözükmüyordu. Hive'de esaret hayatı yaşayan Rus elçilik heyeti bu sefer de Habaş Sultan tarafından görüşmeye çağrıldı. Bu görüşmede Hohlov'un Buhara hanı İmamkulu ile ne görüştüğünü soran Habaş Sultan ayrıca elçilik heyetinin Buhara'dan getirdiği Rus esirleri de gözaltına alarak onlara işkence yapmıştır (Hilkova, 1879, s. 412). Habaş Sultan, Buhara'dan alınan bu esirlerin Müslüman olduğunu ve İslam hukukuna göre Hiristiyan bir ülkeye gönderilemeyeceğini iddia etmiştir (Hilkova, 1879, s. 414). Bunun üzerine İlbars Sultan'ın çarlığa göndermek için Hohlov ile beraber yola çıkan elçisi Makhtambay devreye girerek, Rusların, Müslümanlara kötü muamele etmediğini, söylentilerin abartıldığını ifade ederek Habaş Sultan'1 esirler konusunda ikna etmiştir (Hilkova, 1879, s. 416-417). Tarafların arasında yapılan müzakere neticesinde Hohlov, Habaş Sultan'a hediyeler sunarak esirler için de ayrı bir ücret ödemiştir. Ayrıca İlbars Sultan'ın öldürtmek istediği kardeşi Arap Sultan'ın da elçilik heyeti ile beraber Moskova'ya götürülmesi kararlaştırılmıştır. Hohlov ve maiyeti zorlu Hive macerası sonrası 22 Ekim'de Astarhan'a vararak diplomatik misyonunun sonuna gelmiştir.

Hohlov, 1622 yılının Ekim ayındaki Rusya'ya geri döndükten sonra bu yolculuğu sırasındaki talihsiz vakıalardan kaynaklı 472 ruble ek bir masraf çıktığını bildirmiştir. Bu kayıpların tamamının tanzimi yapılmış ve buna ek olarak elçilik görevinin başarıyla tamamlanmasından ötürü de 40 ruble değerinde kamka (ipekten ve desenli kumaş) ve altın işlemeli atlas kumaş ve 4 grivnilik kupa veya şamdan verilmesi emredilmiştir (Veselovskiy, 1891, 62).

\section{Sonuc}

XVII. yüzyıl Rus Çarlığının çok yönlü çıkar ilişkilerinde bulunduğu ve bilhassa Türkistan ve İran coğrafyası ile yakın temaslar kurmak istediği karmaşı bir (Smutnoe Vremia 1598-1613) dönemdi. $\mathrm{Bu}$ kaotik dönem 1613 yılında Romanov hanedanlığının ilk temsilcisi Mihail Federoviç'in (1613-1645) Rusya'da Çarlığı devralmasıyla son bulmuştur. Ancak Federoviç tahta çıktığında Moskova harap olmuş ve devlet mali olarak çöküş evresine girmişti. Karışıklık döneminin karakteristik özelliği olarak yönetim boşlukları oluşmuş haliyle Rusya'nın yeni elde ettiği Astarhan gibi merkezi gücün hissedilmediği yerlerde ayrılıkçı hareketler başlamıştır. İvan Daniloviç Hohlov'un böyle bir dönemde Astarhan ve daha sonra Buhara'ya elçi olarak gönderilmesi Rus Çarlı̆̆ının bu karmaşık dönemi atlattığının ilan edilmesine dayanmaktadır. Bunun yanı sıra diplomatik olarak Türkistan hanlıkları ile uzun müddet irtibat kurmayan çarlık yönetimi, bu misyonla Rus esirlerini de bahane ederek bölgede keşif seferlerini devam ettirmektedir. Rus Çarlığının Türkistan'daki yayılmacı siyasetinin dinamiklerini oluşturan keşif

\footnotetext{
${ }^{13}$ Buhara ve Hive devlet teşkilatında devlet memurlarına verilen en yüksek rütbelerden biridir. Hanedan mensuplarının koruyuculuğu, yetişmesi gibi çeşitli görevlerde bulunan bu görevliler Han'ın yokluğunda hükümeti yönetebilmekteydi Bkz. (Burton, 1997, s. Xï̈; Ükten, 2018, s. 146; Hatunoğlu, 2017, s.491).
} 
maiyetindeki bu münasebetlerin bir nevi Çarlığın bozkır halkları üzerindeki hâkimiyetini de güçlendiren bir araç olduğu söylenebilir.

Hohlov'un bölgede kurduğu ilişki ağı düşünüldüğünde Hive ve Buhara yöneticilerinin Çarlık yönetiminden çok da çekinmedikleri ve maddi fayda gözettikleri anlaşılmaktadır. Zaten bu dönemde Rus resmi temsilcilerinin gönderilmesi her ne kadar esirler ve ticari ilişkiler bağlamında düşünülse de asıl misyon bozkır halklarını tanımaya yöneliktir. Ancak Hohlov kendisine verilen talimatnameye harfiyen uyarken, bölgeyi tanımlayacak bilgilerin yüzeysel kalması Rus Çarlığının sonraki keşif seferlerinde elçilik maiyetinin içerisinde en az bir jeodezi uzmanı koymalarına sebep olmuştur. Rus esirleri kurtarma girişiminde kendisinden önce bölgeye gönderilen elçilik heyetlerinden daha başarılı olan Hohlov, bölge içerisindeki feodal rekabet ve mücadeleyi de resmetmeyi başarmıştır

\section{Ekler:}

\section{Ek-1 Hohlov'un Talepnamesi}

Çar Mihal Federoviç'e bendeniz köleniz İvaşko Hohlov, geçen 128. yılın 13. Haziran'ında Kazan'da bana hükümdarlığınızın emirnamesi ve vazifesi gönderilmiş ve onda Buhara Hanı İmamkulu'ya elçilik görevi hizmetine atandığım yazılmıştı ve benim görevi yapmak için serbest bırakılmam konusunda hükümdarlığınızın boyarlarından biri olan Knez Boris, Mihailoviç Lıkov ve maiyetine de sizin bir emirnameniz ulaştırılmıştı. Bu emirnamede benim derhal Ürgenç elçisiyle Astrahan yolundan Buhara'ya gitmem emredilmiști. Boyarlarınızdan olan Knez Boris, Mihailoviç Lıkov ve hizmetindekiler Kazan'dan elçilerle Buharalı ve Ürgençli elçileri ile yollamış ve aynı ay içerisindeki 21.günde yani kısa bir süre içerisinde göreviniz için hemen tarafimca hazırlıklara başlanmış ve yolda lazım olacak eşyaların temini için kulunuz bendeniz her şeye bedelinin iki mislini ödemiştir. Astrahan'daki voyvodalarınız ise benim Buhara'ya deniz yoluyla gitmem için vakit güz iken beni bir gemiye bindirdiler. Denizdeki yolculuğumuz hayli vaktimizi almıştı ve sonra geminin demir attığı yerde kimsenin olmadığı Tyunkaragan'a vardık. Lakin bu deniz seyahati gemiyi kullanılamaz hale getirmiş ve içerisindeki eşyalarımız suya batmış ve hayvanlarımız boğulmuştu. Buhara Hanı İmamkulu'ya elçilik görevi için hizmetinizdeki diğer adamlarınızla yollanmış olan bendeniz kulunuz kıyıya çıkmıştım. Bugünün ertesinde Tyunkaraganlı Türkmen askerler tarafindan bendeniz kulunuz ve diğer hizmetlilerinizle beraber kuşatma altına alınarak bir kaya parçasının üzerinde iki gün iki gece geçirdik. Bu uzun bekleyişten sonra onlar üzerimize doğru gelmişler ben de Ürgençli elçi Rahim Kulu'yu onlara yollamıştım. Sonra Ürgençli elçi Rahim Kulu bize bir ikazda bulunarak sadece Buhara Hanı'na gittiğimizi sizin tarafinızdan yollandığımızı söylemememi, aksi halde bizi öldüreceklerini söylemişti. Hünkârım, Ürgençli daha sonra Türkmenlerle biraz dolaşmış, bize Ürgenç'e gidene kadar refakat edecek kılavuz vermeleri için onlarla görüşmüştü. Türkmenler ise Ürgençli elçiye Ürgenç Hanı ve hanlığı, Han'a yakın kişiler hakkında üst üste sorular sorarak onun gerçekten Ürgençli olup olmadığını ve kendilerini kandırıp kandırmadığını anlamaya çalıştılar. Hünkarımız, böylece Ürgençli elçi uzun uzadıya sordukları soruları açıklamış ve nihayetinde kendinin doğru söylediğine onları inandırmış ve onlar da: sadece siz (Ürgençli Elçi) ve Rus elçi ücretimizi/iaşemizi verin biz de arabalarınızın ve kılavuzlarınızın menzile nasıl varacaklarını öğretelim dediler. Bendeniz kulunuz, bu Türkmenlerden arabalarınıza ve kılavuzlarınıza bir miktar para ödedik. Başlangıç olarak da biz bu adamlara 10 yuet? (юетей) dana eti, kaliteli deri ve varil... 15 kova tarafimızdan verildi. Bu insanlarla anlaştık, hünkarımız, aralarında güvenilir olanlar da dahil önümde 20 kişi yer almış, bize kendi inanışlarında ölümü, soygunu, fenalığı ve her türlü zararı uzaklaştırdıklarını düşündükleri kuvars verdiler ve bizi, arabalarımızı ve personelimizi Ürgenç'e Arap Han'a ulaştırdılar. Böylece, Karahanlılar bendeniz kulunuzun önünde giderek koruma görevi üstlendiler. Ve konvoyumuzun bu koruması için hünkârım çok yüksek bir bedel istediler: her bir araba ve her bir deve için 5 ruble. Ve ben, kulunuz bendeniz, arabaları kiralayıp atları yüksek fiyata satın aldım. Ve denizden 15 verst gittiğimizde arabalarımız ve satın aldığımız atlarımız soyguncular tarafından alındılar ve bizi 
bıraktılar. Bendeniz kulunuzu hünkârımız bütün personelimizle esir aldılar ve orada 10 hafta kaldık. Bundan sonra bize tekrar at arabası ve at satın almamız için gelenler olmuş bu sefer onlar bizi korumuş ve bize herhangi bir zarar vermemişlerdir. Bir diğer seferinde de onlardan istemeyerek pahalı bir biçimde atları satın aldım ve arabayı kiraladım, çünkü çocuklarımla gidecek yerimiz yoktu. Hünkârımız, bizi öldürecekleri konusunda bize yalan söylemek istemişler. Arap Han'ın yanında çocuklarımla, bendeniz kulunuz, bizi Buhara'ya varmak için topraklarından geçmemize müsaade etsin diye birçok hayvan (kiraladım). Bu şekilde, hünkarımız, bendeniz kulunuz, Devletinizin işlerini resmi talimatlarınıza göre halletmiş oldum. Daha sonra Buhara'dan, Ürgenç'e geri döndüm. Ürgençliler, Rus Birliği'nin Efendisi, Hünkârımız, Buhara Hanı'nın serbest bıraktığını hayvanlarım, erişebildiklerim ve Buhara Hanı'nın bana verdiklerini, zoraki kiraladıklarımın tümünü ve tüccarların hayvanlarını çaldılar. Ve ben kulunuz, Hive'den Astrahan'a yolladığım Yurtlu Tatar tımarlılarını Ürgenç'den çıkmaları ve Kızılkak dağından Astrahan'a gitmeleri için kendi atlarımı verdim ve yeni atlara daha fazla para ödedim. İşte böyle Hünkârımız; Ürgenç topraklarından bozkıra ve oradan da Astrahan'a geçerken yolda beni Astrahanlı Voyvoda, Yurt Tatarlarının tımarlıları ve streletsler karşıladı. Voyvoda, Astrahan'daki diğer Voyvodalardan bana mesaj getirmiş ve mesajda; beni Kabaklı iskelesindeki gemiye götürmek için Ürgenç Hanlarından emir aldıklarını ve benim Astrahan'a gitmem için önce bu gemiye gitmem gerektiği yazıyordu. Ve ben, Efendimiz, bu tımarlıların getirdikleri mesaj üzere iskeledeki gemiye gitmek için Ürgenç'den aldığım atlarla bu iskeleye kadar gittim ve oradan da Astrahanlı Voyvodaların yolladığı tımarlılarla Astrahan'a vardım. Ve ben, yanımdakiler ve atlarımız bozkırda epey geceler geçirdik. Ve ben, kulunuzun, Türkmenlerden, Ürgençli Arap Han ve onun çocuklarının soygunundan, at ve deve temininden, uzun süren yolculuk için pek çok araba kiralamamdan, Türkmenlerin ölen adamına ödediğim bedelden, beni Astrahan'a yollayan tımarlılar için ödediğim bedelden ve Astrahan'a gitmek için yolladığım atlardan ve deniz iskelesinde benim için bekleyen gemi için ödediğim bedelden dolayı 472 ruble kaybettim. Efendimiz, ben kulunuz, Ürgenç'de iken Arap Han'ın oğlu Afgan Han'ın isteği üzerine kardeşi ile Kızılbaş Han'1 ziyaret ettim. Ve ben, hünkârımız, Afgan Han istedi diye, Han'ın amcası İsen Bay ile görüşmek için yanına gittim. Kızılbaşlara gitmemesi ve kendi ülkesinin hizmetine girmesi için görüşmüş ve siz, Hünkârımız, hizmeti için İsen Bay'a çarlık maaşı lütfetmiştiniz. Han'a ben, kulunuz bendeniz, uzunca bir süre göndermesi konusunda konuşmuş ve amcası, Efendimiz, Afgan Han'1 Çarların Çarı olan siz Efendimizin ülkesine getirdim. İnayetli Çar Hazretleri ve Rusya’nın tamamının Yüce Knezi Mihail Feodoroviç, bendeniz kulunuza resmi hizmetlerim sırasındaki kayıplarımdan doğan bedeli bağışlayın ki Tanrı nasıl sizi bağışladıysa beni de öyle bağışlasın! Rusya'nın tamamının Yüce Knezi, Efendimiz Çar Hazretleri merhamet edin, yalvarırım (Veselovskiy,1892, ss. 62-65).

\section{Ek-2 Hohlov'un Talepnamesi}

Tupkaragan'da batan gemi ve denizde batan malları ve sefer için hediye olarak verilen atlar ve develerin boğulması nedeniyle bunların yerine alınan veya kiralanan atlar ve develere ödenen kayıplar için yardım talep ediyordu:

30 çuval kuru gıda, 20 polot (kangal vs.) domuz jambonu, 100 konserve sığır eti; ve 15 pud şeker ile Urgenç'e gitmek için yola çıktığımızda, bendeniz İvan kendime ve yanımdakilere 3 at satın aldım, bu atlara 18 ruble 2 grivni verdim, bunun yanı sıra malların ve yiyeceklerin taşınması için 5 deve kiraladım ve develerin her birine 5 ruble ödenmesi konusunda anlaştım, amirlere 5 ruble ve 15 fiçı şarap verdim ve tüccarlara 5 юетей (yuet) kırmızı deri verdim. Onlar, denizden biraz uzaklaşırken bu atların tamamı kaçıştılar. Diğer seferinde ise bunlar atlarını ve develerini Beyaz Mescit'e kadar başka bir yerden kiraladılar ancak bunlar da kaçtılar. Onlar, burada 6 hafta mahpusta kalmışlardı ve az daha açlıktan öleceklerdi. İvan daha sonra hapisten Adnu(?) nam Urgençli Türkmen Tüccar vasıtasıyla Urgenç Hanı Arap Han'a gizlice haber yollamıştı. Bu tüccardan 3 at satın alınmış ve 20 ruble verilmişti. Ayrıca Hohlov, aynı Türkmen'e 3 юети deri ve 6 ruble verdi. Atlar için 6 ruble daha ve kendilerine refakat eden bölgenin yerlilerine gömlek, pantolon, 50 kopeyk para verdi.

Turkish Studies - Social, 15(1) 
Türkmenlerin ölen adamları için de 125 arşın bez, 100 yuet deri, 10 тафилей? Ugor bıçağ 1,120 yemek tabağ 1 verildi. Buna ek olarak 10 yuet deri verildi ki fiyatı 20 rubleye gelmekte yani 1 юет 2 ruble etmekteydi. Biz mescitten, gözaltından çıkmak için, bendeniz İvan, resmi işlerim ve Buharalı elçi için deve satın aldım ve bunun için Buharalı elçiye 14 ruble daha ödedim.

Ürgençli Arap Han kendi adamlarından bana 2 asker göndermiş, İvan ise bu askerlere 3 yuet (yani 6 ruble) değerinde deri hediye etmiş; bunun yanı sıra tüccarlardan 2 ruble değerinde 2 arşın bez satın almıştı. Bendeniz İvan, Beyaz dağlara gitmek için 2 deve satın aldım ve bunun için 32 ruble verdim.

Ürgenç'e vardıklarında, İvan, Habaş Han'a 5 ruble değerinde en yüksek kaliteden 2 (arşın) deri, tanesi 2 ruble 25 kopeykten 2 цки (çeki) çamaşır, tanesi 50 kopeykten 10 tane tabak, kavanoz şarap ve tüccarlardan alınma bezi hediye olarak taşımıştım. Ayrıca kendisine seyahatimde refakat eden 2 subaya kendi cebimden 3 ruble ve kavanoz (damacana da olabilir) şarap verdim. Hive'de Arap Han'a da hediyeler sundum, 5 rublenin yarısı kadar değerde iki цки çamaşır, 5 ruble değerinde yani 2 yuetlik deri, kavanoz (damacana) şarap, değeri 50 kopeek olan 10 tane tabak, Han için tüccarlardan alınan kumaştan verdim. Seyahat için Han'ın oğlu Nazar Şahoğlu'na kendi cebimden 3 ruble değerinde 2 yuetlik orta kalite deri ve değeri 2 ruble 25 kopeyk olan 1 цки kumaş verdim. Ayrıca kendi verdiği emir mektubumda: 1 ruble değerinde deri, 13 altın ve 2 para verdim.

Bu seyahat sırasında Arap Han'ın oğullarından olan Şerif Sultan, Bendeniz İvan'a tehdit dolu bir mesaj göndererek kendi yetki alanı altında bulunan topraklardan olan terkedilmiş Vezir kasabasından geçtiği için kendisine ödeme yapması gerektiğini belirtiyordu. Bunun üzerine efendimiz ben İvan yine kendi cebinden olmak üzere 2 yuetlik deri ve 2 цки kumaş veriyor bunların değeri ise 7 ruble 2 grivniye denk gelen bir ödeme yaptım.

Hanların gümrüklerindeki memurlar da gümrük vergisi almamışlar ancak onlara da 25 altın değerinde deri ve kumaş hediye etmiştim.

Ürgenç'den Buhara'ya kadar eşyaların ve personelin sevkiyatı için 3 deve kiralanmış ve bunlar için 6 ruble 10 altın vermiştim.

Ürgenç topraklarından gidiş, Hive'de konaklama, Buhara'dan geçiş sırasında da maiyetindeki asker ve memurların yemek ihtiyac1, atların ve develerin beslenmesi; Beyaz mescitlerdeki gözaltı sırasında ve Ürgenç'de ekmek, su ve yakacak ihtiyacı; Buhara'ya gidene kadar ise atlar için arpa ve saman ihtiyaçları için ise toplamda 15 ruble harcanmıştı. İvan, Buhara'nın beylerinden (voyvodalarından) olan Mirzabek'e kendi cebinden karşılanmak üzere 3 yuetlik deri, 2 цки kumaş, 10 tabak ve tüccarlardan alınmış bez hediye etmiş ve bunlar toplam 9 ruble tutmuştu. Buhara'dan Semerkant'a kadar eşlik eden korumalara ise kendi cebinden karşılanmak üzere 3 ruble değerinde черлено? bez verdim.

Rusya'nın tamamının hükümdarı ve Büyük Knez Mihail Federoviç'in emri üzerine Hohlov, değeri 35 ruble olan 40 samur kürkü ve küp şarabı Buhara Hanı'na hediye olarak götürmüştü. Buhara Hanı ayrıca İvan'dan 8 ruble değerinde (Турскую демешковой) ok aldığını yazmıştı. Han'ın amcası Nadir Divanbeg'e ise emirnamede yazılanların yerine getirilmesi için rüşvet verdim. Bu rüşvet 6 ruble 11 altın ve 4 paraya karşılık gelen 3 yuetlik tabaklanmış deri ve 2 ruble 25 kopeyklik kumaştan oluşmaktaydı. Çar'ın İvan'a getiren memurlara ise İvan, değeri 2 ruble olan külah, kaftan, kuşak, tabaklanmış deri, çamaşır (içlik) hediye etmişti. İvan Han'dan hediye olarak ise Türk aygırı, kadife bordo kaftan ve Hive'de Arap Han seyislere 30 altın para (lira) vermişti.

Semerkant'a varıldığında streletslerin (askerlerin) yiyecek olarak verilecek hiçbir şeyi kalmamış ve İvan, streletslere kendi cebinden para ödyerek yiyecek dağıtmıştı.

Buhara ve Semerkant'a giderken İvan, maiyetindeki memurlar, atlar ve develerle beraber beslenmiş, 9 ay içerisinde yakacak odun için 44 ruble para ödemişti ki Buharalı beyler 
(voyvodalar) bunun dışındaydı. Buhara'dan giderken 9 at 6 deve satın almış, bu develerden 2'si Ürgenç'e geldiklerinde ölmüştü. 9 at için toplamda 35 ruble, 6 deve için ise 49 ruble ödemişti. Buhara'dan Astrahan'a kadar ise 4 kez ödeme yaptı.

Hive'de İlbars Sultan'a ise tamamı 6 ruble değerinde atlas kumaş ve 2 tane pahalısından işlemeli havlu; Ürgenç Hanı Abeş (Habaş) ve diğerlerine, Ruslara yakın olduğu düşünülen kişilere ve İvan'ın mallarını 2 yol üzerinden göndermek için 2 ruble, 20 altın değerinde ipek kuşak, 13 altın 2 para değerinde kindyak (kaftan kumaşı); Buhara Hanının İvan'a verdiği altın işlemeli başlık; İvan'ın Abeş'in amcası Koçek Mirza'nın aldıkları; koşum takımı, koyu renkli iyi kalite bez ve oğlu Mametyar'a ipek kumaş. Bunun yanı sıra İvan, Abeş Han'ın 2 ruble 50 kopeyk aldığını ve Abeş’ten kiraladığ atlardan birinin ölmesi üzerine de 6 ruble daha verdiğini yazıyor.

Ürgenç’ten yola çıkan İvan, Tatar stepleri üzerinden geçmiş ve Astrahan'a gitmek üzere gemiye varmış, gemiden limana yanaştıktan sonra koşumu, eyeri üzerinde at ve pelerin için Tatarlara 3 ruble 20 altın vermiş, diğerlerinin atlarını ise tüccarlardan almıştı.

İvan Bovat'ta iken 4 devesi ölmüş ve bunların yerine 27 ruble ödeyerek 5 at satın almıştı. Ayrıca 5 araba daha almış ve arabalara 7 buçuk ruble ödemişti.

Buhara'dan çıktıktan sonra Urgenç topraklarında 4 adamıyla kışı ve yazı geçirmiş; adamları, atları ve develerini doyurmak için bu süre içerisinde toplamda 59 buçuk ruble harcamıştı.

$\mathrm{Bu}$ talepnamede İvan'ın belirttiğine göre toplam harcama stoklar hariç 473 ruble olarak hesaplanmıştı ${ }^{14}$. Denizin altında kalan stoklar şöyleydi: 30 çuval kuru gıda, 20 domuz jambonu, 100 parça tuzlanmış et kneyada rafine edilmiş 15 pud (1 pud 16,38 gr) şeker, 17 fiçı şarap ki bunlar Türkmenlere verilmiş, bunun karşılığında kendilerini Arap Han ve Buhara Hanı'na götürmeleri istenmişti. Bunun yanı sıra Yurgenli Abeş Han'a altın işlemeli sarık alınmış ve bunun ücreti Buhara Hanı'nın lütfu (hediyesi) olduğu için yazılmamıştı.

İvan'ın esir alınmasına ise özel ilgi gerekmektedir (Veselovskiy, 1891, ss. 65-69).

\section{Kaynakça}

Abduraimov, M. (1955), "Perviy Russkiy Kupeçeskiy Karavan v Taşkent: 1738-1739 gg”. İzvestia An UZSSR, Taşkent, № 6. S. 87-93.

Apollova N. G., (1948) Prisodinenie Kazahstana k Rossi, Akademii Nauk Kazahskoy SSR, AlmaAta.

Aydoğmuşoğlu, Cihat, (2011) Şah Abbas ve Zamanı, Ankara Üniversitesi Doktora Tezi, Ankara.

Barthold, V. V., (2004). Rusya ve Avrupa'da Oryantalizm (Çeviren: Kaya Bayraktar, Ayşe Mera), İstanbul 2004: Küre Yayınları.

Burton, Audrey, (1997) The Bukharans: Dynastic, Diplomatic and Commercial History, 15501702, Richmond: Curzon Press,

Burton, Audrey, (1998) "Russian Slaves in Seventeenth-Century Bukhara", Post- Soviet Central Asia, Ed. Touraj Atabaki and John O'Kane, Tauris Academic Studies, Leiden, Amsterdam, ss. 345-365.

Bohlen, Avis, (1966), "Changes in Russian Dipmolacy under Peter the Great" Chaiers $d u$ Monde, S. 7, N. 3, 341-358.

${ }^{14}$ Daha önce her yerde 472 olarak yazılmıştı.

Turkish Studies - Social, 15(1) 
İnalcık, Halil, (1948) "Osmanl1-Rus Rekabetinin Menşei ve Don-Volga Kanalı Teşebbüsü (1569)", Belleten, XII, S. 46, TTK, Ankara, 349-402.

Hatunoğlu, Nurettin, (2017) "Buhara Hanlığı”, Avrasya’nın Sekiz Asrı Çengizoğulları, Ötüken, İstanbul, 482-526.

Jenkinson, A., (1886). Early Voyages and Travels to Russia and Persia (Vol. I). (Edited by. E. Delmar Morgan, C. H., Coote), New York.

Jukovskiy, S.V. (1915). Snoşeniya Rossii s Buharoii Hivoy za Poslednee Trehsotletıe, Petrograd.

Lunin, B. V., (1988), İstoria Uzbekistana v İstoçnikah: İzestia Puteşestvennikov Geografov $i$ UçenIh XVI-Pervoy Polovin XIX v, Taşkent.

Khodarkovsky, Michael (2002), Russia's Steppe Frontier: The Making of a Colonial Empire, 1500-1800. Bloomington and Indianapolis,

Karamzin, Nikolay (1843)) İstoriya Gosudarstva Rossiyskago, IX, Sanktpeterburg.

Knighting, David Aaeron, (2008) Ivan Khoklov: Russian Envoy to the Court of Imam Quli Khan, MA thesis, Indina Universitiy.

Koç, Dinçer (2017), "XVI.-XIX. Yüzyıllarda Buhara Hanlı̆̆ı'’na Gelen Rus Diplomat ve Askerleri”" TDA, C. 115, S. 227, s. 61-90.

Koç, Dinçer (2018) "Hive (Harezm) Hanlı̆̆ı" Avrasya'nın Sekiz Asrı Cengizoğulları, (Hayrunnisa Alan, İlyas Kemaloğlu Hz.), Ötüken.

Kurat, Akdes Nimet, (2011) Türkiye ve İdil Boyu (1569 Astarhan Seferi, Ten-İdil Kanalı ve XVIXVII. Yüzyıl Osmanl-Rus Münasebetleri, TTK, 2011, 136-156.

Kurat, Akdes Nimet, (1999). Rusya Tarihi. Ankara: Türk Tarih Kurumu.

Makleyev, (1890), İstoriçeskiy Obzor Turkestana i Nastupatelnago Dvijeniya v Nego Russkih, S. Petersburg.

Nikitin, Afanasiy (2018), Üç Deniz Ötesinde Seyahat, Çev. Serkan Acar, TTK, Ankara.

Özkan, Murat, (2019) "Buhara, Petersburg ve İstanbul Arasında Diplomasi Trafiği: Molla İrnazar Maksutov Elçiliği”, Gazi Türkiyat, Bahar, 24, 165-183.

Özkan, Murat (2019) "Rus Emperyal Yayılmasının Bir Vasıtası Olarak: Orenburg Neplüyev Askeri Okulu”, 4. Uluslararası Bilimsel Araștırmalar Kongresi) (UBAK), Ankara 2019. ss. 65-82.

Özkan, Murat, (2017) Çarlık Rusyası'nın Türkistan Sahasını İşgalinde Bir Rus General: Mihail Dimitrieviç Skobelev, Sakarya Üniversitesi Sosyal Bilimler Enstitüsü Basılmamış Doktora Tezi, Sakarya.

Saray, Mehmet, (1990). Rus İşgali Devrinde Osmanlı Devleti ile Türkistan Hanlıkları Arasındaki Siyasi Münasebetler (1775-1875), İstanbul.

Sbornik Knyazya Hilkova, (1879) "Stateynı Spisok Posolstva v Buhariyu Dvoryanina İvana Hohlova”, S. Petersburg, 388-439.

Sela, Ron, (2013) Seventeenth-Century Russian Diplomatic Mission to Central Asia, (edited by Nile Green), Writing Travel in Central Asian History, Bloomington and Indianapolis: Indiana University Press, 69-88.

Ükten, Selim Serkan “16-18. Asırlarda Buhara Hanlığı'na Gelen Batılı Seyyahlar ve Seyahatnameleri, Eskişehir Osmangazi Üniversitesi Sosyal Bilimler Dergisi, S. 18(2), Aralik 207, 141-143. 
Ükten, Serkan, (2018) Buhara Hanlı̆̆ı'nın Askeri Teşkilatı (1500-1868), TTK, Ankara.

Ünal, Fatih, (2010) Rus Emperyazlizmine Karşı Stepte Büyük Başkaldırı, Sultan Kenasarı, İlgi Kültür Sanat, İstanbul.

Türker, Özgür, (2019) "Keşfetmek ve Tanımlamak: 17 ve 18. Yüzyıl Rus Seyyahlarına Göre Buhara”, Seyyahların İzinde Türkitan, (Mustafa Gökçe Ed.), Pegem Yay., 73-110.

V. Teplova, (1891). Russkie Predstavitelli v Tsargrade 1496-1891, İstoriçeskiy Oçerk, S. Petersburg.

Veselovskiy, N.İ. (1891). İvan Daniloviç Hohlov, S. Petersburg, 48-72. 